\title{
Factors Influencing the Formation of Tobacco-Specific Nitrosamines in French Air-Cured Tobaccos in Trials and at the Farm Level ${ }^{*}$
}

\author{
by

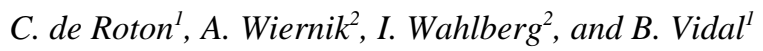 \\ ${ }^{1}$ Altadis/Institut du Tabac, Domaine de la Tour, 24100 Bergerac, France \\ ${ }^{2}$ Swedish Match, Research \& Analysis, 11885 Stockholm, Sweden
}

\section{SUMMARY}

Several trials the results of which are compiled in this paper, were carried out at the Tobacco Institute of Bergerac (ITB) and in the area nearby from 1996 to 2003. The objective was to study the formation of tobacco-specific nitrosamines (TSNA) in dark air-cured and burley tobaccos during curing and post-curing treatment under the conditions of cultivation, curing and storage commonly applied by the growers in the south-western part of France. For experimental purposes special treatments were performed in certain trials.

The results showed that the main genetic trait involved in the formation of TSNA is the propensity of a variety to convert nicotine to nornicotine (NN). In addition, the ability of a variety to lose water rapidly limits the formation of nitrite and hence also the formation of TSNA. Furthermore, agricultural practices that led to an increase of alkaloid concentrations in the tobacco leaves also led to an increase of TSNA concentration. Priming, a mode of harvest which speeds up the cure, as compared to stalk-cutting, as well as low temperatures during curing, limit the formation of TSNA, but do not yield tobaccos of the best quality. Ventilation in the barn plays a major role, and the leaves cured in well ventilated curing structures, such as plastic sheds, generally contained smaller amounts of TSNA than leaves cured in a conventional curing barn. The results also indicated that the TSNA concentrations may increase after the end of cure, if the cured tobaccos were kept hanging in the barn under humid conditions. The concentration of TSNA may also continue to increase, whereas nitrite concentrations tend to decrease, when the leaves are kept in bales.

It can be concluded that the French climatic conditions with moderate temperatures and low relative humidity at the time of curing, are favourable for the production of aircured tobaccos with a good quality and low TSNA concen- trations $(1.5-3.5 \mu \mathrm{g} / \mathrm{g})$, provided that the variety has low $\mathrm{NN}$ content, the nitrogen fertilization is moderate, the curing is performed in a well ventilated environment, the tobacco is taken down and stripped as soon as it is cured, and the bales are stored as briefly as possible before the leaves are threshed and stabilized. [Beitr. Tabakforsch. Int. 21 (2005) 305-320]

\section{ZUSAMMENFASSUNG}

Im Tabakinstitut in Bergerac (ITB) und der umliegenden Gegend wurden in der Zeit von 1996 bis 2003 mehrere Versuche durchgeführt, deren Ergebnisse in dieser Arbeit dargestellt werden. Ziel dieser Untersuchungen war es, die Entstehung der tabakspezifischen Nitrosamine (TSNA) bei dunklen luftgetrockneten Tabaken und Burley-Tabaken während und nach der Trocknung unter den Anbau-, Trocknungs- und Lagerungsbedingungen, wie sie üblicherweise von den Pflanzern im Südwesten Frankreichs angewandt werden, zu erforschen. Aus experimentellen Gründen erfolgten in einigen Versuchen spezielle Behandlungen.

Die Ergebnisse haben gezeigt, dass die wichtigste bei der Entstehung der TSNA beteiligte genetische Eigenschaft die Fähigkeit einer Varietät ist, Nikotin in Nornikotin umzuwandeln. Außerdem wird durch die Fähigkeit einer Varietät, auf schnelle Weise Wasser zu verlieren, die Nitritbildung und somit auch die Bildung der TSNA begrenzt. Darüber hinaus führen agronomische Praktiken, die eine Erhöhung der Alkaloidkonzentrationen in den Tabakblättern zur Folge haben, ebenfalls zu einer Zunahme der TSNA. Sowohl die Blatternte, eine spezielle Erntemethode, die den Trocknungsvorgang im Vergleich zur Ganzpflanzenernte beschleunigt als auch niedrige Temperaturen während der Trocknung verringern die Bildung der TSNA, führen jedoch nicht zu Tabaken der besten Qualität. Die

*Received: $22^{\text {nd }}$ September 2004 - accepted: $28^{\text {th }}$ February 2005 
Ventilation in den Trocknungsschuppen spielt eine herausragende Rolle und Blätter, die in gut ventilierten Trocknungsstrukturen getrocknet werden, wie zum Beispiel in Schuppen aus Kunststoff, enthalten normalerweise geringere Mengen an TSNA als Blätter, die in konventionellen Trocknungsschuppen getrocknet werden. Die Ergebnisse haben außerdem gezeigt, dass die TSNA-Konzentrationen auch am Ende der Trocknung ansteigen können, wenn die getrockneten Tabake weiterhin unter Einwirkung von Feuchtigkeit in den Schuppen hängen bleiben. Die TSNAKonzentrationen können auch dann weiter zunehmen, wenn die Blätter in Ballen gelagert werden, wohingegen Nitritkonzentrationen in diesem Fall abnehmen.

Es kann die Schlussfolgerung gezogen werden, dass sich die klimatischen Bedingungen in Frankreich mit gemäßigten Temperaturen und einer niedrigen relativen Luftfeuchtigkeit zur Zeit der Trocknung auf die Erzeugung luftgetrockneter Tabake von guter Qualität und mit niedrigen TSNA Konzentrationen $(1,5-3,5 \mu \mathrm{g} / \mathrm{g})$ günstig auswirken, vorausgesetzt die Varietät hat einen niedrigen Nornikotingehalt, die Stickstoffdüngung ist moderat, die Trocknung erfolgt in gut ventilierter Umgebung, der Tabak wird, sobald er getrocknet ist, abgenommen und entblättert, und die Ballen werden so kurz wie möglich gelagert, bevor die Blätter zerkleinert und stabilisiert werden. [Beitr. Tabakforsch. Int. 21 (2005) 305-320]

\section{RESUME}

Les résultats présentés dans cette publication proviennent de plusieurs expérimentations réalisées à l'Institut du Tabac de Bergerac (ITB) et dans sa proche région, de 1996 à 2003. Ces expérimentations avaient pour objectifs d'étudier la formation des nitrosamines spécifiques du tabac (TSNA) dans les tabacs Brun et Burley séchés à l'air naturel, pendant et après la dessiccation, dans les conditions de culture, de séchage et de conservation habituellement rencontrées chez les planteurs du Sud-Ouest de la France. Des traitements spécifiques ont été appliqués dans quelques essais pour les besoins de cette étude.

Les résultats ont montré que la principale caractéristique génétique impliquée dans la formation des TSNA est l'aptitude de la variété à convertir la nicotine en nornicotine. De plus, l'aptitude de la variété à sécher rapidement limite la formation de nitrite et, par conséquent, de TSNA. Par ailleurs, les pratiques culturales qui augmentent les teneurs en alcaloïdes des feuilles accroissent aussi leurs teneurs en TSNA. La cueillette en feuilles, mode de récolte qui permet une dessiccation plus rapide que la cueillette en tiges, ainsi que des températures basses pendant le séchage, limitent la formation de TSNA, mais ne conduisent pas à l'obtention de la qualité la meilleure. L'aération du séchoir joue un rôle primordial, et les feuilles provenant de séchoirs bien ventilés, comme les serres «plastique », contiennent en général moins de TSNA que les feuilles issues de séchoirs traditionnels. Les résultats indiquent également que les teneurs en TSNA peuvent augmenter après la fin du séchage si les tabacs secs sont maintenus à la pente en conditions humides. Les teneurs en TSNA peuvent aussi continuer d'augmenter, tandis que les teneurs en nitrite peuvent diminuer, durant la conservation des feuilles en balles.
En conclusion, les conditions climatiques françaises, que caractérisent des températures modérées et de faibles humidités relatives au moment de la dessiccation, sont favorables à la production de tabacs séchés à l'air naturel de bonne qualité et pauvres en TSNA $(1,5-3,5 \mu \mathrm{g} / \mathrm{g})$, pourvu que la variété soit pauvre en nornicotine, la fertilisation azotée modérée, le séchage réalisé dans une atmosphère bien ventilée, le tabac effeuillé dès qu'il est sec, et les balles conservées le moins longtemps possible avant le battage et la stabilisation des feuilles. [Beitr. Tabakforsch. Int. 21 (2005) 305-320]

\section{INTRODUCTION}

During the past two decades, numerous studies have been carried out all over the world on the accumulation of tobacco-specific nitrosamines (TSNA) in different types of tobacco, the reason being the toxicity of this family of chemical compounds in laboratory animals (1).

The mechanisms of the formation of TSNA during curing have been well documented both for air-cured (2-5) and fluecured $(6,7)$ tobaccos. In the case of air-cured tobaccos which are the topic of the present study, it is now generally agreed that TSNA result from the nitrosation of tobacco alkaloids by nitrosating agents derived from nitrite. The nitrite itself is formed by microbial reduction of nitrate during the browning and stem-drying stages of air-curing. There is also evidence that TSNA may continue to be formed in cured tobacco when the tobacco is kept hanging in the barn after the end of cure $(8,9)$. Only a few studies have been dedicated to the accumulation of TSNA in air-cured tobaccos under European conditions of production and curing $(10,11)$, and to the possible formation of TSNA in cured tobaccos during the storage of bales at the farm level.

The objectives of the present study are to report the results of several trials and surveys performed since 1996, which have been focused on the formation of TSNA in burley and dark air-cured tobaccos (DAC) under the conditions of cultivation, curing and on-farm storage commonly implemented in France. The purpose was to evaluate the effects of variety, agricultural practices, curing environment and storage on nitrite and TSNA accumulation.

\section{MATERIALS AND METHODS}

\section{Varieties used in the studies}

The trials and surveys presented here comprised DAC varieties, a type of tobacco still grown in France, and burley varieties. The varieties were chosen either for their share in French tobacco production or for particular traits, such as their propensity to convert nicotine to nornicotine $(\mathrm{NN})$ : this is the case of the varieties TC01 and BB $16 \mathrm{NN}$ cultivated for scientific purposes only. The main characteristics of the varieties used are presented in Table 1.

\section{Cultivation}

Unless otherwise specified, all plants were cultivated according to common agricultural practices implemented in France (see Table 2). 
Table 1. Main characteristics of the varieties used in the trials and studies carried out at the Tobacco Institute of Bergerac (ITB) from 1996 to $2003^{\text {a }}$

\begin{tabular}{l|ccccc}
\hline Tobacco & Variety & Characteristics & Share in 2003 & Origin & NN propensity \\
\hline DAC & ITB 1000 & $F_{1}$ MS & 920 ha/1100 ha & ITB & low \\
& ITB 1105 & $F_{1}$ MS (light DAC) & 28 ha/1100 ha & ITB & low \\
& TC01 & $F_{1}$ MF (light DAC) & for studies only & ITB & high \\
Burley & ITB 501 & $F_{1}$ MS & 920 ha/3200 ha & ITB & medium \\
& BB16NN & fertile line & for studies only & ITB & high \\
& BB16A & fertile line & low & hy 17 & high \\
& B217 & fertile line (light burley) & 163 ha/198 ha & Germany & ha \\
\hline
\end{tabular}

${ }^{\text {a }} \mathrm{DAC}=$ dark air-cured tobacco; $\mathrm{MF}=$ male fertile; $\mathrm{MS}=$ male sterile

Table 2. Main cultural practices implemented in the trials and studies carried out at ITB from 1996 to 2003

\begin{tabular}{|c|c|c|c|c|c|}
\hline \multirow[b]{2}{*}{ Tobacco } & \multirow{2}{*}{$\begin{array}{c}\text { Plant } \\
\text { population } \\
\left(\text { plants ha }{ }^{-1}\right) \\
\end{array}$} & \multicolumn{3}{|c|}{ Fertilization $\left(\mathrm{kg} \mathrm{ha}^{-1}\right)$} & \multirow{2}{*}{$\begin{array}{l}\text { Topping height } \\
\text { (leaves/plant) }\end{array}$} \\
\hline & & $\mathrm{N}$ & $\mathrm{P}_{2} \mathrm{O}_{5}$ & $\mathrm{~K}_{2} \mathrm{O}$ & \\
\hline DAC & 35700 & $250-280$ & 20 & 250 & $15-16$ \\
\hline Burley & 28500 & $250-280$ & 20 & 250 & $17-18$ \\
\hline
\end{tabular}

The seedlings were grown in a float system $^{1}$ from midMarch to the beginning of May.

They were transplanted into the fields of the Tobacco Institute of Bergerac (ITB), in sandy-loam soils with $1.2-1.7 \%$ organic matter and a $\mathrm{pH}$ of 6.5 to 7.0 .

As several methods of harvesting and different curing environments were used in the trials, they will be described separately in the relevant sections.

\section{Curing structures}

The curings took place in different curing structures:

a) A conventional curing barn for air-curing of DAC and burley tobaccos, tile roofed, brick walled, $8 \mathrm{~m}$ wide, $30 \mathrm{~m}$ long, $10 \mathrm{~m}$ high, with openings of about $25 \%$ of the side walls. The four tiers were loaded with either whole plants (DAC: 15-20 plants $/ \mathrm{m}^{3}$, burley: 12-16 plants $/ \mathrm{m}^{3}$ ) or primed leaves (DAC: $250-300$ leaves $/ \mathrm{m}^{3}$, burley: 200-240 leaves $/ \mathrm{m}^{3}$ ).

b) Plastic sheds, now widespread among the growers, with black plastic roof, sides that may be completely raised for a higher ventilation, and one tier of plants. An air heater may be used and this was either fitted with a heat exchanger, or air was heated by a direct flame. Heated air was pushed through by a fan in a shaft for an even distribution. The heater, fan and side lifting were operated either automatically or manually according to the curing programme.

c) ERATIS climatic chambers that can hold about 200 tobacco leaves. The chambers were regulated with respect to relative humidity $(\mathrm{RH})$ and temperature $\left(T,{ }^{\circ} \mathrm{C}\right)$.

\footnotetext{
${ }^{1}$ In the float system, the tobacco seeds are directly seeded on a medium that fills the cells of polystyrene trays. The seeded trays are floated on a fertilising solution from which the roots of the seedlings can take up nutrients and water when they emerge through the basal hole of the cells.
}

d) A room conditioned with respect to $\mathrm{RH}$ and temperature, where either stalk-cut plants or primed leaves were cured.

e) A bulk-curing barn traditionally used for flue-cured tobacco with a direct flame gas burner.

f) Experimental electrically heated bulk-curing barns.

\section{Sampling}

Samples were taken at harvest $(\mathrm{H})$, at the end of yellowing (EOY), at the end of browning (EOB), after curing (EOC) or after storage of cured leaves. In some trials, only cured leaves were sampled. Whole leaves were split into midrib $\left(\mathrm{stem}^{2}\right)(\mathrm{S})$ and lamina (L). The samples taken before end of cure were freeze-dried. Samples of cured tobacco were force air dried at $30^{\circ} \mathrm{C}$. Midribs and lamina, or lamina only, were ground to $500 \mu \mathrm{m}$ and the samples of powder were either immediately dispatched to analysis, or stored in closed plastic jars at $-18{ }^{\circ} \mathrm{C}$ until shipment.

\section{Physical parameters}

Water activity $\left(a_{\mathrm{w}}\right)$ was measured using the $\mathrm{a}_{\mathrm{w}}$-meter Novasina $\mathrm{a}_{\mathrm{w}}$ Lab IC 500; RH and temperature during curing were recorded using data-loggers TESTO 454.

\section{Chemical analyses}

Individual alkaloids - nicotine, NN, anatabine, anabasine and myosmine - were determined at ITB using an internal method. A total of $100 \mathrm{mg}$ of $500 \mu \mathrm{m}$ ground tobacco were mixed in a $100 \mathrm{~mL}$ jar with $3 \mathrm{~mL}$ of hydrochloric acid (1 $M$ ) and $4 \mathrm{~mL}$ of sodium hydroxide $(5 M)$. Then, $10 \mathrm{~mL}$ of dichloromethane containing $2 \mathrm{mg}$ of quinine as internal standard were added. The mixture was then shaken for 20 min on an orbital shaker. The extract remained undisturbed for $10 \mathrm{~min}$ and was filtered through a phase separator filter (silicone treated paper Whatman). A total of $2 \mathrm{~mL}$ of the filtrate were put in a vial, from which $10 \mu \mathrm{L}$ were analysed by high performance liquid chromatography (HPLC). Separation of the tobacco alkaloids was achieved with a Varian Prostar System analytical HPLC (Pump 230 SDM,

\footnotetext{
2 The word midrib is used when the midribs are obtained by hand cutting. The word stem is used when they are obtained by threshing. Both midrib and stem are referred to by $(\mathrm{S})$.
} 
Table 3. Conditions ( $\mathrm{RH}$, temperature) of air-curing in a conventional curing barn (Trial 1 - ITB 1996)

\begin{tabular}{l|c|c|c}
\hline Conditions & Yellowing & Browning & Stem drying \\
\hline $\mathrm{RH}$ & $\begin{array}{c}8-90 \% \\
16-25^{\circ} \mathrm{C}\end{array}$ & $\begin{array}{c}70-80 \% \\
12-20{ }^{\circ} \mathrm{C}\end{array}$ & $\begin{array}{c}55-80 \% \\
10-20{ }^{\circ} \mathrm{C}\end{array}$ \\
\hline
\end{tabular}

ultraviolet detector 330, autosampler Samplers Set 410) using a normal phase Macherey-Nagel column cc 125 /4 nucleosil 50-5. The solvent system used was an organic mixture of acetonitrile $70 \%$ and methanol $30 \%$ (v/v) containing $5 \mathrm{~mL}$ of $\mathrm{H}_{2} \mathrm{O}$ and $1 \mathrm{~mL} / \mathrm{L}$ of triethylamine. Elution was performed at a solvent flow rate of $1 \mathrm{~mL} / \mathrm{min}$. Quantification of nicotine, NN, anabasine, anatabine and myosmine was determined at $258 \mathrm{~nm}$ with a diode-array detector. The different alkaloids were identified by comparing their retention times and ultaviolet (UV) vis spectra with authentic standards and internal standard (quinine) peaks.

Individual TSNA - N'-nitrosonornicotine (NNN), $N^{\prime}$ nitrosoanabasine (NAB), $N$ '-nitrosoanatabine (NAT) and 4(methylnitrosamino)-1-(3-pyridyl)-1-butanone (NNK) were determined by the gas chromatography-thermal energy analyser (GC-TEA) method in several laboratories (Swedish Match, Ökolab and Global Laboratory Services).

- The method used by Swedish Match is described in Reference 12.

- At Global Laboratory Services, $1 \mathrm{~g}$ of ground tobacco is sonicated in $20 \mathrm{~mL}$ of a sodium hydroxide solution $(0.01 N)$. The samples are then extracted by a thin layer of liquid-liquid extraction, using diatomaceous earth extraction cartridges. The eluent is concentrated and analysed by GC using a TEA for detection. Controls used are the 1R4F and 2R4F monitors obtained from the University of Kentucky. $\mathrm{N}$-Nitrosoguacoline is also used as a surrogate spiked on each sample to evaluate each sample individually. With each batch of samples, a multiple point calibration curve is used to obtain the data, and the instrument is calibrated with each batch.

- At Ökolab, $0.5 \mathrm{~g}$ of ground tobacco is weighed into a $50 \mathrm{~mL}$ beaker. The amount of $20 \mathrm{~mL}$ of buffer $(33.1 \mathrm{~g}$ $\mathrm{Na}_{2} \mathrm{HPO}_{4} .12 \mathrm{H}_{2} \mathrm{O}, 11.3 \mathrm{~g}$ citric-acid monohydrate and $3.6 \mathrm{~g}$ ascorbic acid per litre) and $100 \mu \mathrm{L}$ ISTD I ( $N$ nitroso-pentyl-3-picolyl-amine) are added. The samples are swirled over night on a magnetic strirrer. The solution is applied onto an Extrelut column where it remains half an hour. The column is eluted with $70 \mathrm{~mL}$ dichloromethane. The eluate is concentrated up to 2-5 mL and applied onto an aluminium oxide column ( $8 \mathrm{~g}$ aluminium oxide is suspensed in dichloromethane and filled into a glass column). The TSNA are then eluted with $25 \mathrm{~mL}$ dichloromethane:acetone (4:1). A total of $100 \mu \mathrm{L}$ ISTD II ( $N$-nitroso-dibenzylamine) is added and the eluate is reduced to a volume of exactly $1 \mathrm{~mL}$.

The samples are quantified by means of GC-TEA. Quantification is done by means of external standard solutions. After quantification, samples are exposed to UV-light (365 nm) over night for qualitative coverage (nitrosamines are destroyed).
Nitrite was determined as $\mathrm{NaNO}_{2}$ by a spectrophotometric procedure using an RFA 300 rapid flow analyser or a flow solution 4 (OI Analytical).

All results are reported on a dry weight basis.

\section{Statistical analysis}

For practical reasons, not all the trials had replications. When a statistical analysis of the results was feasible, means were compared using the analysis of variance (Anova) and the criterion of Newman-Keuls $(p=0.05)$. Significantly differing means or homogeneous groups of means were quoted with different letters $(a, a b, b, \ldots)$.

\section{RESULTS AND DISCUSSION}

\section{Effect of variety}

TSNA are formed by the reaction of alkaloids and $\mathrm{NO}_{\mathrm{x}}$ derived from nitrite. Being a secondary amine, $\mathrm{NN}$ is more reactive than nicotine, which is a tertiary amine. As a consequence, two genetic traits were deemed to be important for the accumulation of TSNA: a) the ability of the variety to convert nicotine to $\mathrm{NN}$, and $\mathrm{b}$ ) the rate of water loss from the tissues, which affects the water activity $\left(a_{\mathrm{w}}\right)$ and consequently determines the time period for bacterial growth $(4,5)$.

a) Nicotine to nornicotine conversion: Trial 1, which was carried out in 1996, aimed at highlighting the effects of variety and of type of curing on the formation of TSNA (10). Three varieties of DAC tobacco, differing in their propensity to convert nicotine to NN: ITB 1105 (low propensity), ITB 1000 (slightly higher propensity) and TC01 (very high propensity) were used. They were cured according to four different curing procedures: air-curing of stalk-cut plants (SCAC), air-curing of primed leaves (PAC), curing of primed leaves in a bulk-curing barn (modified "flue-curing": $\mathrm{FC}$ ) and air-curing of lamina separated from the midrib at the end of yellowing (ACL).

The SCAC and PAC air-curing procedures were performed in a conventional air-curing barn under the normal curing conditions implemented at ITB, as indicated in Table 3. When the curing was completed, cutters and upper middle leaves were stripped from the stalk-cut plants. Primed leaves (PAC and FC) were taken from the stalk positions of cutters and upper middle leaves (leaves) and were cured. The complete cure took 55 days in the SCAC regimen and 20-28 days in the PAC regimen.

The leaves of the ACL regimen were first cured on the stalk with the other SCAC plants until the end of yellowing, cutters and leaves were then detached from the stalk, the midrib was removed and the two halves of lamina were cured in a curing chamber $\left(25-27^{\circ} \mathrm{C}, \mathrm{RH} 75 \%\right)$. The complete cure took 10-15 days for the cutters and 15-20 days for the leaves.

The curing in the bulk-curing barn (FC) was performed with the use of a direct flame gas burner. The parameters 32-38 ${ }^{\circ} \mathrm{C}, \mathrm{RH} 85-90 \%$ were applied for yellowing and 32-38 ${ }^{\circ} \mathrm{C}$, RH $82-85 \%$ for browning, while stem drying was performed at temperatures of $45{ }^{\circ} \mathrm{C}$ and $\mathrm{RH}$ of 40-50\%. The complete cure took 20 days. 
Table 4. Nicotine (Nic), NN concentrations and ratios of NN/total alkaloids (NN/Alk) in cured midrib and lamina in three varieties of tobacco cured according to four different curing procedures: air-curing of stalk-cut plants (SCAC), air-curing of primed leaves (PAC), modified flue-curing (FC) and air-curing of lamina (ACL) (Trial 1 - ITB 1996)

\begin{tabular}{|c|c|c|c|c|c|c|c|c|c|c|c|c|c|}
\hline \multirow[b]{2}{*}{ Variety } & & \multicolumn{3}{|c|}{ SCAC } & \multicolumn{3}{|c|}{ PAC } & \multicolumn{3}{|c|}{$\mathrm{FC}$} & \multicolumn{3}{|c|}{$\mathrm{ACL}$} \\
\hline & & Nic (\%) & NN (\%) & NN/Alk (\%) & Nic (\%) & NN (\%) & NN/Alk (\%) & Nic (\%) & NN (\%) & NN/Alk (\%) & Nic (\%) & NN (\%) & NN/Alk (\%) \\
\hline \multirow[t]{2}{*}{ ITB 1105} & Midrib & 0.33 & 0.04 & 10.8 & 0.34 & 0.06 & 15.0 & 0.49 & 0.03 & 5.8 & - & - & - \\
\hline & Lamina & 3.21 & 0.13 & 3.9 & 3.04 & 0.46 & 13.1 & 3.49 & 0.28 & 7.4 & 3.15 & 0.13 & 4.0 \\
\hline \multirow[t]{2}{*}{ ITB 1000} & Midrib & 0.25 & 0.04 & 13.8 & 0.33 & 0.09 & 31.4 & 0.39 & 0.03 & 7.1 & - & - & - \\
\hline & Lamina & 3.16 & 0.25 & 7.3 & 2.74 & 0.38 & 12.2 & 3.08 & 0.41 & 11.7 & 3.63 & 0.15 & 4.0 \\
\hline \multirow[t]{2}{*}{ TC01 } & Midrib & 0.04 & 0.15 & 78.9 & 0.03 & 0.15 & 83.3 & 0.15 & 0.11 & 42.3 & - & - & - \\
\hline & Lamina & 0.84 & 1.16 & 58.0 & 0.34 & 1.61 & 82.6 & 0.63 & 1.20 & 65.6 & 0.70 & 1.03 & 59.5 \\
\hline
\end{tabular}

Table 5. Concentrations of individual TSNA in cured lamina $(\mu \mathrm{g} / \mathrm{g})$ of three varieties of tobacco. Means of all four different curing procedures: air-curing of stalk-cut plants (SCAC), aircuring of primed leaves (PAC), modified flue-curing (FC) and air-curing of lamina (ACL) (Trial 1 - ITB 1996). Significantly differing means are quoted with different letters $(a, b)$.

\begin{tabular}{l|cc|c|c|c|c}
\hline & \multicolumn{3}{|c|}{ Cutters } & \multicolumn{3}{c}{ Leaves } \\
\cline { 2 - 7 } & ITB 1105 & ITB 1000 & TC01 & ITB 1105 & ITB 1000 & TC01 \\
\hline \multirow{2}{*}{ NNN } & 0.4 & 1.3 & 6.0 & 0.8 & 1.6 & 5.8 \\
NAT & 0.6 & 0.7 & 0.4 & 0.6 & 0.4 & 0.5 \\
NNK & 0.4 & 0.5 & 0.2 & 0.3 & 0.3 & 0.1 \\
TSNA & $1.5 \mathrm{a}$ & $2.4 \mathrm{a}$ & $6.6 \mathrm{~b}$ & $1.7 \mathrm{a}$ & $2.3 \mathrm{a}$ & $6.4 \mathrm{~b}$ \\
\hline
\end{tabular}

Table 4 shows the concentrations of nicotine and $\mathrm{NN}$ as well as ratios of $\mathrm{NN} /$ total alkaloids in cured lamina and midribs of the upper middle leaves. It can be concluded that, independent of the curing procedure, cured leaves of TC01 had the highest NN concentrations and the highest $\mathrm{NN} /$ total alkaloid ratios. The lowest $\mathrm{NN}$ concentrations and the lowest $\mathrm{NN} /$ total alkaloids ratios were generally found in cured leaves of ITB 1105. Air-curing of primed leaves yielded higher NN concentrations and higher NN/total alkaloids ratios than air-curing of stalk-cut plants in all three varieties and in both midribs and lamina. The $\mathrm{NN} /$ total alkaloids ratio was systematically higher in midribs than in lamina, except for leaves that had been cured in the bulk-curing barn, using conditions that curtails the chemical transformations in midribs.

As shown in Table 5, the different levels of conversion had a strong effect on the formation of TSNA, especially on NNN formation in cured leaves. In lamina of both cutters and leaves, the concentrations of TSNA, and, especially, of $\mathrm{NNN}$, increased as the level of conversion increased in the three tobacco varieties. As a result, the composition of individual nitrosamines varied according to the variety. Thus, in a converter variety such as TC01, NNN predominated largely, whereas NNK and NAT were proportionally more abundant in ITB 1000 and ITB 1105. The effects of the curing procedures on TSNA concentrations will be discussed below.

b) Water activity: It is well documented that the reduction of nitrate, resulting in the formation of nitrite, is mediated by nitrate-reducing microorganisms, especially bacteria $(4,5)$. The growth of microorganisms is dependent upon the level of water activity $\left(a_{\mathrm{w}}\right)$, i.e. the amount of water available to the bacteria in tobacco tissues. Water activity is defined as equal to $1 \%$ of the relative humidity of the atmosphere surrounding the tobacco at equilibrium. As a general rule, most bacteria are unable to grow at an $a_{\mathrm{w}}$ less than 0.9 (13).

Not all tobacco varieties lose water at the same rate. Therefore, the decrease of $a_{\mathrm{w}}$ during curing is not the same in all varieties. This has an effect on the growth of bacteria, and, therefore, on the formation of nitrite, as can be shown in the following example from Trial 2 carried out in 2002 (11).

Trial 2: Upper middle leaves of the burley varieties BB16NN and ITB 501 were primed and air-cured in an ERATIS climatic chamber, used as a curing chamber. The temperature was set at $25{ }^{\circ} \mathrm{C}$ throughout the cure. $\mathrm{RH}$ was set at $85 \%$ during yellowing, at $78 \%$ during browning, and at $65 \%(15 \mathrm{~h})$ and $40 \%(9 \mathrm{~h})$ in daily alternation during stem drying. The value of $a_{\mathrm{w}}$ was measured at harvest and at the end of each curing phase. Individual alkaloids, nitrite and TSNA were determined in lamina and midribs separately (see Table 6).

We can observe from Figure 1 that the decrease of $a_{\mathrm{w}}$ during yellowing and browning was faster both in midrib (S) and lamina (L) of BB16NN than in those of ITB 501. Also, the water activity decreased faster in lamina than in midrib in both varieties. The $a_{\mathrm{w}}$ value reached 0.9 in lamina at day 8 for BB $16 \mathrm{NN}$ and at day 12 for ITB 501. In the case of midribs, $a_{\mathrm{w}}$ reached 0.9 at day 13 for BB16NN and at day 17 for ITB 501. In agreement with this, nitrite was formed in smaller amounts in lamina $(1-2 \mu \mathrm{g} / \mathrm{g})$ than in midribs (up to $25 \mu \mathrm{g} / \mathrm{g}$ ) (Figure 2). In addition, the nitrite concentrations were higher in midribs of ITB 501 than in midribs of BB16NN. It is also noteworthy from Figure 3, that the increase of the NN concentration was more pronounced in midribs than in lamina. As a result, the ratio of NN/total alkaloids increased more dramatically in midrib than in lamina (Figure 4). Therefore, the ratio of NN/total alkaloids in midribs appears to be a good indicator of conversion. The uneven curve of $\mathrm{NN}$ concentration and $\mathrm{NN} /$ total alkaloid ratio for ITB 501 is most likely a result of the relative instability of this variety with respect to $\mathrm{NN}$ conversion.

TSNA were mainly formed during stem drying (Figure 5). The accumulation was higher in midribs, 8.7 and $10.0 \mu \mathrm{g} / \mathrm{g}$ of BB16NN and ITB 501, respectively, than in lamina, 1.9 and $1.1 \mu \mathrm{g} / \mathrm{g}$ of BB16NN and ITB 501, respectively. This is evidently a result of the higher nitrite concentrations in midribs than in lamina, which in turn is due to a longer time period for bacterial growth. However, despite the fact that BB16NN had much lower nitrite concentrations than ITB 501 in midribs, BB16NN formed almost the same amount 
Table 6. Concentrations of total alkaloids, NN, nitrite and TSNA and the ratios of NN/total alkaloids in lamina and midrib at harvest $(\mathrm{H})$, at the end of yellowing (EOY), at the end of browning (EOB) and at the end of curing (EOC) during aircuring of primed leaves of BB16NN and ITB 501 in a curing chamber (Trial 2 - ITB 2002) ${ }^{\text {a }}$

\begin{tabular}{|c|c|c|c|c|}
\hline \multirow[b]{2}{*}{ Sampling } & \multicolumn{2}{|c|}{ BB16NN } & \multicolumn{2}{|c|}{ ITB 501} \\
\hline & Lamina & Midrib & Lamina & Midrib \\
\hline \multicolumn{5}{|c|}{ Total alkaloids \% } \\
\hline $\mathrm{H}$ & 4.62 & 0.93 & 4.33 & 0.83 \\
\hline EOY & 5.69 & 0.83 & 5.01 & 0.81 \\
\hline EOB & 5.69 & 0.85 & 5.70 & 0.96 \\
\hline EOC & 5.80 & 0.97 & 4.72 & 0.81 \\
\hline \multicolumn{5}{|c|}{ Nornicotine \% } \\
\hline $\mathrm{H}$ & 0.22 & 0.02 & 0.18 & 0.03 \\
\hline EOY & 1.06 & 0.13 & 0.80 & 0.10 \\
\hline EOB & 1.28 & 0.41 & 0.44 & 0.14 \\
\hline EOC & 1.31 & 0.47 & 0.77 & 0.25 \\
\hline \multicolumn{5}{|c|}{ NN/total alkaloids \% } \\
\hline $\mathrm{H}$ & 4.8 & 2.3 & 4.2 & 3.9 \\
\hline EOY & 18.6 & 15.8 & 16.0 & 12.3 \\
\hline EOB & 22.5 & 48.7 & 7.7 & 14.9 \\
\hline EOC & 22.5 & 48.3 & 16.3 & 31.5 \\
\hline \multicolumn{5}{|c|}{ Nitrite $\mu g / g$} \\
\hline $\mathrm{H}$ & 2 & 1 & nd & nd \\
\hline EOY & 2 & 3 & 1 & 2 \\
\hline EOB & 2 & 10 & 2 & 9 \\
\hline EOC & 2 & 10 & 1 & 25 \\
\hline \multicolumn{5}{|c|}{$T S N A \mu g / g$} \\
\hline $\mathrm{H}$ & nd & nd & nd & nd \\
\hline EOY & nd & 0.3 & nd & nd \\
\hline EOB & 0.2 & 0.6 & 0.2 & 0.6 \\
\hline EOC & 1.9 & 8.7 & 1.1 & 10.0 \\
\hline
\end{tabular}

${ }^{\mathrm{a}} \mathrm{nd}=$ not detected.

of TSNA as ITB 501.This result is an effect of the higher $\mathrm{NN}$ content in the converter variety BB16NN than in the lower converter ITB 501 (Table 6). This means that the same nitrite concentration leads to higher TSNA values in a high NN converter than in a low NN converter variety, emphasizing that breeders can play a crucial role in the work to minimize TSNA formation $(14,15)$.

\section{Effect of agricultural practices}

Trial 3: With a view to assessing the effects of some agricultural practices on TSNA concentrations in cured tobacco, Trial 3 was carried out in 1998. In this experimental design, 2 levels (Table 7) of the factors variety, nitrogen fertilization, topping height, and type of harvesting and curing were combined in a randomised complete block design of two replications.

The results obtained which are presented in Table 8, show that the level of nitrogen fertilization and topping height had significant and similar effects on total alkaloids and TSNA concentrations. Higher $\mathrm{N}$ fertilization and lower topping height resulted in higher concentrations of total alkaloids and TSNA. However, the type of harvesting and curing did not change significantly any of these concentrations.

The NN concentration and the ratio of NN/total alkaloids were altered only by the type of harvesting and curing. Lamina obtained from cured leaves that had been primed had higher NN concentrations and ratio of NN/total alkaloids than lamina of cured leaves from stalk-cut plants. However, this did not result in significantly higher TSNA concentrations in primed leaves, probably because the faster cure of the primed leaves compensated for their higher NN content.

\section{Effects of curing}

a) Effect of harvesting and curing procedures: Trial 1 provides an assessment of the effect of harvesting and curing on TSNA concentrations in cured tobacco (10). In addition to the effect of variety due to propensity of NN conversion, the data listed in Tables 9 and 10 show that the type of curing has a strong effect on the TSNA concentrations. This is amply illustrated in Figure 6, where the means of the TSNA concentrations for the three varieties are calculated. The ACL curing resulted in the lowest TSNA accumulation, the PAC curing gave slightly higher levels and the SCAC curing had the highest levels both for cutters and leaves. These results may be rationalised by the differences in the rate of curing which affects the growth of bacteria. The fastest cure was that of detached lamina at the end of yellowing (ACL). The cure of primed leaves was slightly longer, and that of whole plants (SCAC) was the longest, see Trial 1. It should also be added that in the ACL curing procedure the leaf was not only detached from the stalk but the lamina was also separated from the midrib which is the highest source of nitrate and moisture.

The regimen FC was a special case, since although being fast, it yielded the highest TSNA concentrations for all three
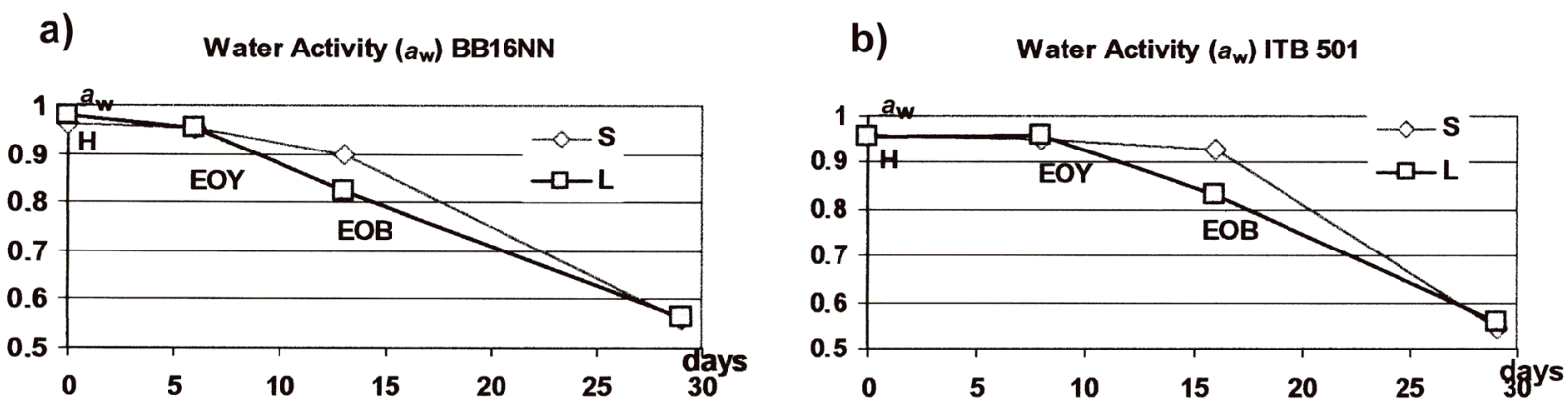

Figure 1. $a_{w}$ Values in midrib (S) and lamina (L) of primed leaves of a) BB16NN and b) ITB 501 at harvest (H), at the end of yellowing (EOY), at the end of browning (EOB) and at the end of curing during air-curing in a curing chamber (Trial 2 - ITB 2002) 
a)

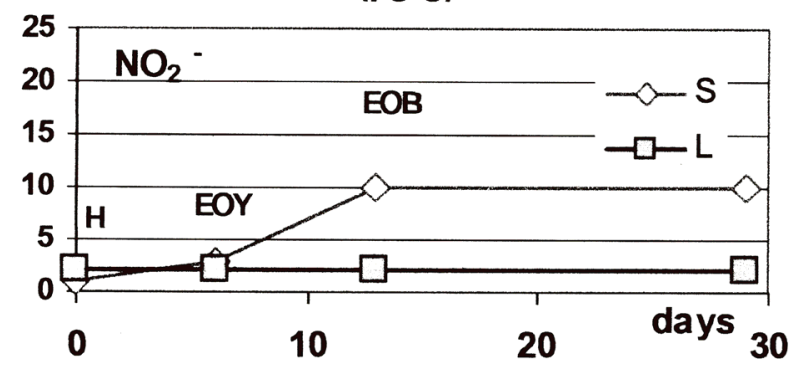

b) Nitrite $(\mu \mathrm{g} / \mathrm{g})$ ITB 501

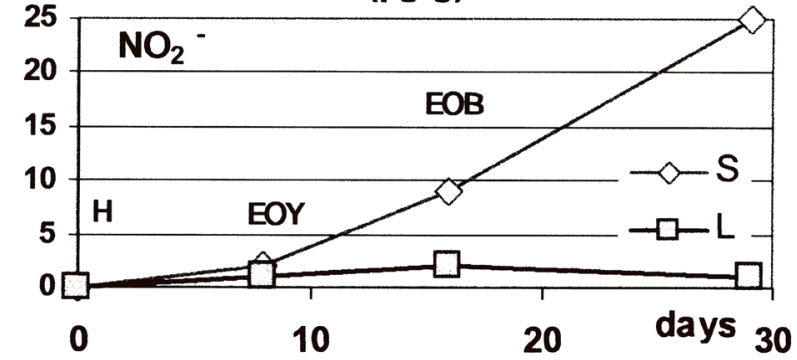

Figure 2. Concentrations of nitrite $\left(\mathrm{NO}_{2}^{-}\right)$in midrib (S) and lamina ( $\mathrm{L}$ ) of primed leaves of a) BB16NN and b) ITB 501 at harvest (H), at the end of yellowing (EOY), at the end of browning (EOB) and at the end of curing during air-curing in a curing chamber (Trial 2 - ITB 2002)

\section{a) Nornicotine BB16NN}

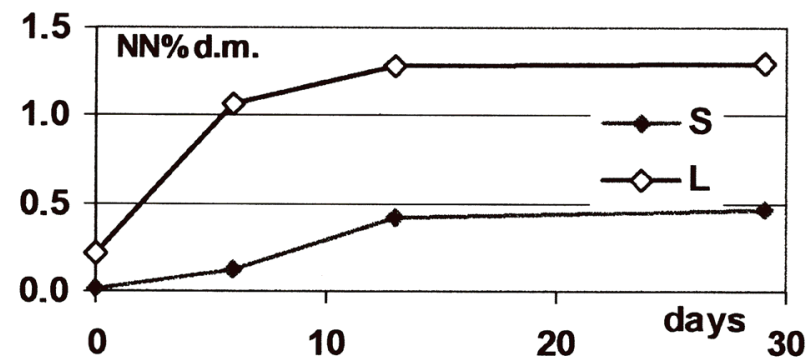

b) Nornicotine ITB 501

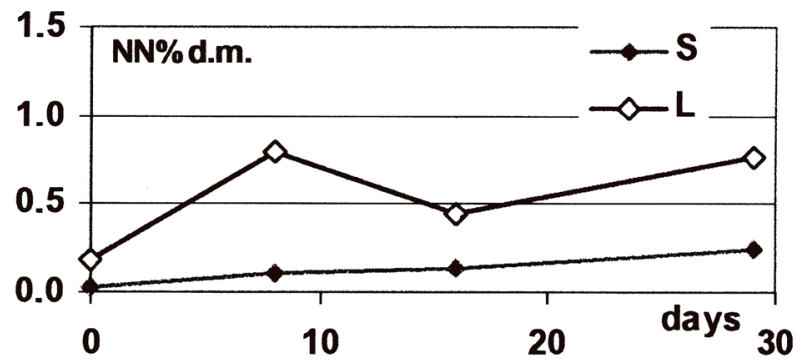

Figure 3. Evolution of NN concentrations (NN\% d.m.) in midrib (S) and lamina (L) of primed leaves of a) BB16NN and b) ITB 501 during air-curing in a curing chamber (Trial 2 - ITB 2002)

a) NN/Alkaloids BB16NN

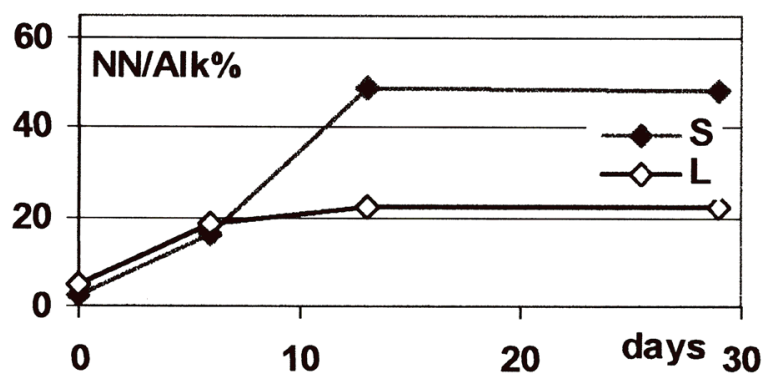

b)

NN/Alkaloids ITB 501

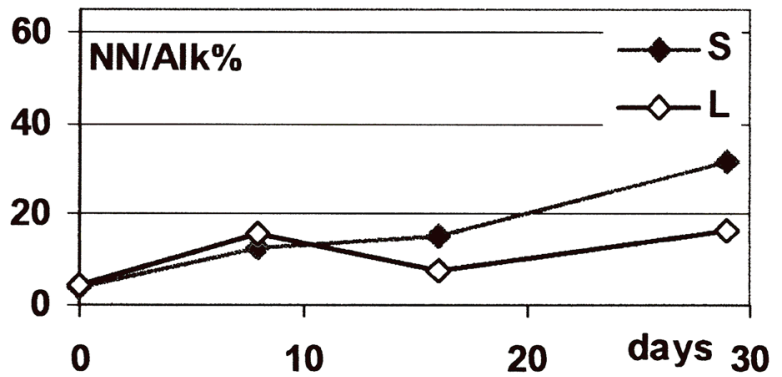

Figure 4. Evolution of the ratios of NN/total alkaloids (NN/Alk) in midrib (S) and lamina (L) of primed leaves of a) BB16NN and b) ITB 501 during air-curing in a curing chamber (Trial 2 - ITB 2002)

a)

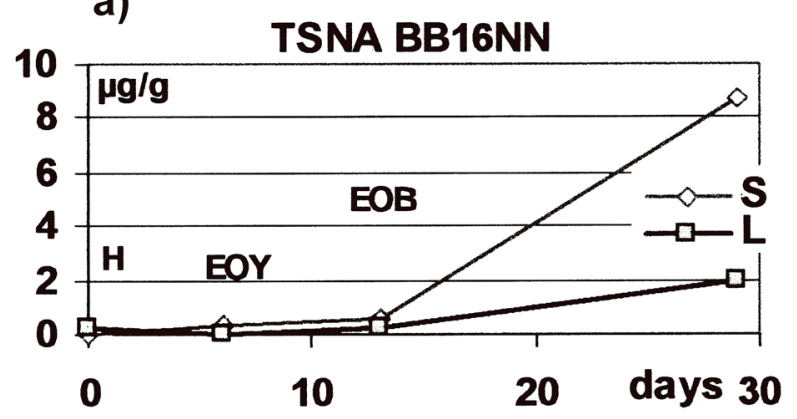

b)

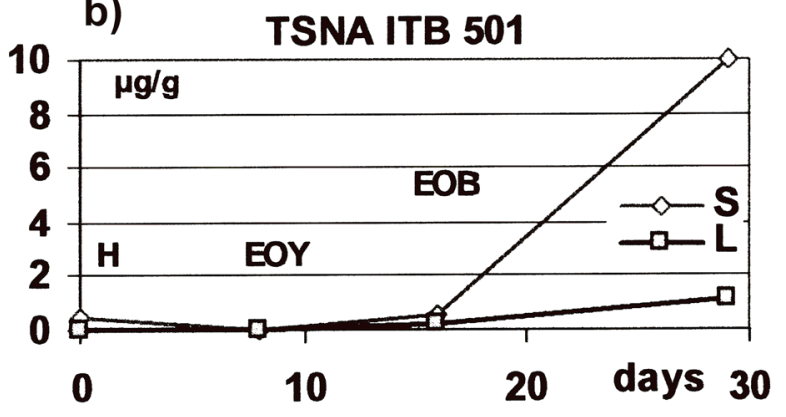

Figure 5. Concentrations of TSNA in midrib (S) and lamina (L) of primed leaves of a) BB16NN and b) ITB 501at harvest (H), at the end of yellowing (EOY), at the end of browning (EOB) and at the end of curing during air-curing in a curing chamber (Trial $2-$ ITB 2002) 
Table 7. Levels of the factors variety, nitrogen fertilization, topping height and type of harvesting and curing in the experimental design (Trial 3 - ITB 1998)

\begin{tabular}{|c|c|c|c|c|}
\hline Level & Variety & N Fertilization & Topping height & Harvesting-curing \\
\hline 1 & ITB 1000 (DAC) & $\mathrm{N} 1: 233 \mathrm{~kg} \mathrm{ha}^{-1}$ & Low: 15-16 leaves/plant & P: primed leaves \\
\hline 2 & ITB 501 (burley) & $\mathrm{N} 2: 403 \mathrm{~kg} \mathrm{ha}^{-1}$ & High:18-20 leaves/plant & SC: whole plants \\
\hline
\end{tabular}

Table 8. Total alkaloids, NN, TSNA concentrations and ratios of NN/total alkaloids in cured lamina - main effects of the factors variety, nitrogen fertilization, topping height and type of harvesting and curing (Trial 3 - ITB 1998). Significantly differing means are quoted with different letters $(a, b)$.

\begin{tabular}{l|c|c|c|c|c}
\hline Factors & Levels & Total alkaloids (\%) & NN (\%) & NN/Alkaloids (\%) & TSNA $(\mu \mathrm{g} / \mathrm{g})$ \\
\hline Variety & ITB 1000 & $5.37 \mathrm{a}$ & $0.55 \mathrm{a}$ & 10.2 & $1.45 \mathrm{a}$ \\
& ITB 501 & $5.89 \mathrm{~b}$ & $0.44 \mathrm{a}$ & 7.5 & $2.59 \mathrm{~b}$ \\
N Fertilization & $\mathrm{N} 1$ & $5.37 \mathrm{a}$ & $0.49 \mathrm{a}$ & 9.1 & $1.48 \mathrm{a}$ \\
& $\mathrm{N} 2$ & $5.90 \mathrm{~b}$ & $0.50 \mathrm{a}$ & 8.5 & $2.56 \mathrm{~b}$ \\
Topping height & Low & $5.62 \mathrm{a}$ & $0.54 \mathrm{a}$ & 9.6 & $2.29 \mathrm{a}$ \\
& High & $4.44 \mathrm{~b}$ & $0.50 \mathrm{a}$ & 11.3 & $1.35 \mathrm{~b}$ \\
Harvest-curing & Primed & $5.51 \mathrm{a}$ & $0.61 \mathrm{a}$ & 11.1 & $2.12 \mathrm{a}$ \\
& Stalk cut & $5.76 \mathrm{a}$ & $0.38 \mathrm{~b}$ & 6.6 & $1.92 \mathrm{a}$ \\
\hline
\end{tabular}

Table 9. TSNA concentrations in cured lamina of cutters in three varieties of dark air-cured tobacco cured according to four different curing procedures: air-curing of lamina (ACL), air-curing of primed leaves (PAC), air-curing of stalk-cut plants (SCAC) and modified flue-curing (FC) (Trial 1 - ITB 1996). Significantly differing means are quoted with different letters (a, ab, b, c). ${ }^{a}$

\begin{tabular}{|c|c|c|c|c|c|c|c|c|c|c|c|c|}
\hline \multirow[b]{2}{*}{ Concentrations } & \multicolumn{4}{|c|}{ ITB 1000} & \multicolumn{4}{|c|}{ ITB 1105} & \multicolumn{4}{|c|}{ TC01 } \\
\hline & $\mathrm{ACL}$ & PAC & SCAC & $\mathrm{FC}$ & $\mathrm{ACL}$ & PAC & SCAC & $\mathrm{FC}$ & $\mathrm{ACL}$ & PAC & SCAC & $\mathrm{FC}$ \\
\hline NNN & 0.4 & 1.1 & 1.3 & 2.2 & nd & 0.1 & 0.7 & 0.9 & 2.0 & 1.7 & 8.8 & 11.4 \\
\hline NAT & $\mathrm{nd}^{*}$ & 0.3 & 1.1 & 1.3 & 0.1 & 0.2 & 0.8 & 1.3 & 0.2 & nd & 0.7 & 0.8 \\
\hline NAB & nd & nd & nd & nd & nd & nd & nd & nd & nd & nd & nd & nd \\
\hline NNK & nd & 0.4 & 0.2 & 1.4 & nd & nd & 0.4 & 1.3 & nd & nd & 0.4 & 0.3 \\
\hline TSNA & $0.4 \mathrm{a}$ & $1.8 \mathrm{ab}$ & $2.6 \mathrm{ab}$ & $4.9 \mathrm{~b}$ & $0.1 \mathrm{a}$ & $0.3 \mathrm{a}$ & $1.9 \mathrm{~b}$ & $3.5 \mathrm{c}$ & $2.2 \mathrm{a}$ & $1.7 \mathrm{a}$ & $9.9 \mathrm{~b}$ & $12.5 \mathrm{c}$ \\
\hline
\end{tabular}

${ }^{\mathrm{a}} \mathrm{nd}=$ not detected.

Table 10. TSNA concentrations in cured lamina of upper-middle leaves in three varieties of dark air-cured tobacco cured according to four different curing procedures: air-curing of lamina (ACL), air-curing of primed leaves (PAC), air-curing of stalk-cut plants (SCAC) and modified flue-curing (FC) (Trial 1 - ITB 1996). Significantly differing means are quoted with different letters (a, ab, b, C). ${ }^{a}$

\begin{tabular}{|c|c|c|c|c|c|c|c|c|c|c|c|c|}
\hline \multirow[b]{2}{*}{ Concentrations } & \multicolumn{4}{|c|}{ ITB 1000} & \multicolumn{4}{|c|}{ ITB 1105} & \multicolumn{4}{|c|}{ TC01 } \\
\hline & $\mathrm{ACL}$ & PAC & SCAC & $\mathrm{FC}$ & $\mathrm{ACL}$ & PAC & SCAC & $\mathrm{FC}$ & $\mathrm{ACL}$ & PAC & SCAC & $\mathrm{FC}$ \\
\hline NNN & nd & 0.5 & 0.6 & 5.3 & nd & 0.4 & 0.6 & 2.3 & 1.1 & 1.6 & 5.5 & 15.1 \\
\hline NAT & nd & nd & 0.3 & 1.4 & nd & nd & 0.6 & 1.9 & nd & nd & 0.4 & 1.5 \\
\hline NAB & nd & nd & nd & nd & nd & nd & nd & nd & nd & nd & nd & nd \\
\hline NNK & nd & nd & nd & 1.2 & nd & nd & nd & 1.1 & nd & nd & nd & 0.5 \\
\hline TSNA & $0.0 \mathrm{a}$ & $0.5 a b$ & $0.9 \mathrm{ab}$ & $7.9 \mathrm{~b}$ & $0.0 \mathrm{a}$ & $0.4 a$ & $1.2 \mathrm{ab}$ & $5.3 b$ & $1.1 \mathrm{a}$ & $1.6 \mathrm{a}$ & $5.9 \mathrm{~b}$ & $17.1 \mathrm{c}$ \\
\hline
\end{tabular}

${ }^{\mathrm{a}} \mathrm{nd}=$ not detected.

varieties. In this case, however, the TSNA were formed by the gas-phase nitrosation of alkaloids with the aid of gaseous $\mathrm{NO}_{\mathrm{x}}$ produced by the direct flame burner (6). A tight relationship between the contents of NN and TSNA is particularly obvious in this curing regimen. As shown in Figure 7, featuring the concentrations of NN, NNN and TSNA in lamina of cutters and leaves of the varieties ITB 1000, ITB 1105 and TC01, the correlation coefficients between NN and NNN and between NN and TSNA are as high as 0.96 and 0.98 , respectively. b) Effect of type of air-curing barn: Ventilation plays a considerable role in the formation of TSNA during aircuring. It governs the decrease of $\mathrm{RH}$, facilitates the removal of carbon dioxide and ethylene produced by the leaves during curing and of nitrogen oxides produced by nitrite, all of which having an effect on microbial growth, nitrite, and NN formation and, therefore, TSNA formation. Ventilation is much more efficient in plastic sheds, which are narrow barns with large side openings, where the plants are hung on a single tier, than in large conventional curing 

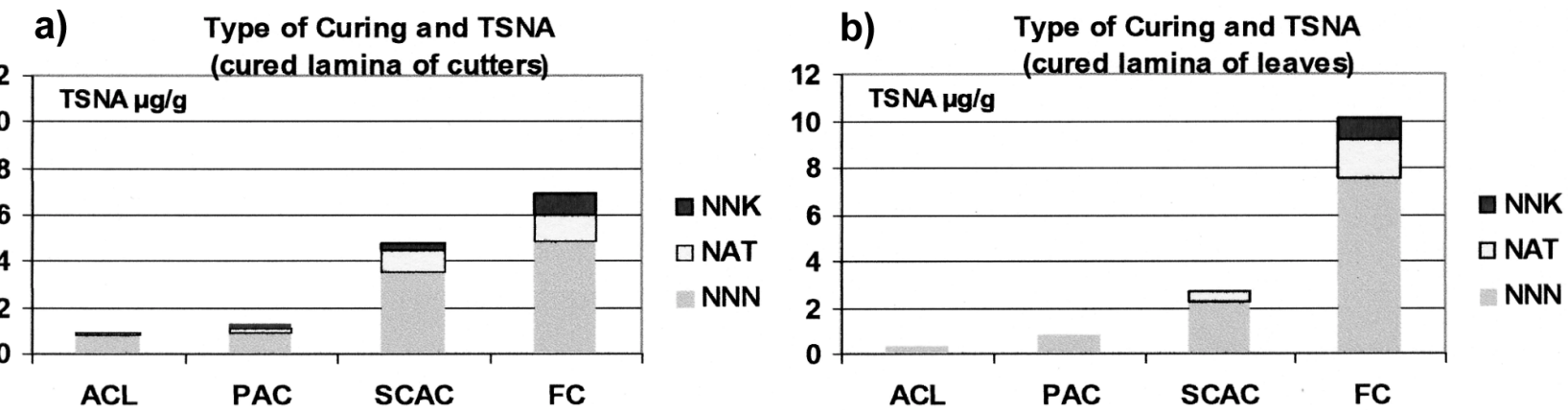

Figure 6. The effect of the type of curing: air-curing of lamina (ACL), air-curing of primed leaves (PAC), air-curing of stalk-cut plants (SCAC) and modified flue-curing (FC), expressed as means of individual TSNA concentrations in a) cured lamina of cutters and b) cured lamina of leaves in the three varieties (Trial 1 - ITB 1996)
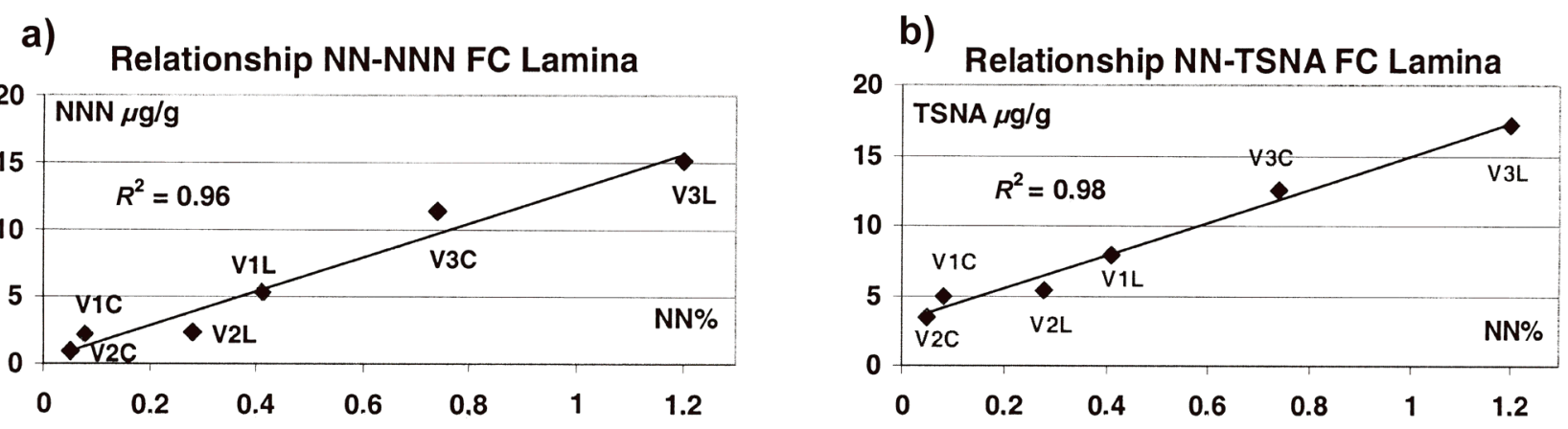

Figure 7. Relationships between a) NN and NNN and b) NN and TSNA concentrations in lamina of cutters (C) and upper-middle leaves (L) of ITB 1000 (V1), ITB 1105 (V2) and TC01 (V3) after a modified flue-curing (FC) in a bulk-curing barn (Trial 1 - ITB 1996)

Table 11. Comparison of TSNA concentrations $(\mu \mathrm{g} / \mathrm{g})$ in cured lamina and midrib of upper-middle leaves after air-curing in a conventional barn and a plastic shed

\begin{tabular}{|c|c|c|c|c|c|c|}
\hline \multirow[b]{2}{*}{ Year } & \multirow[b]{2}{*}{ Type of tobacco } & \multirow[b]{2}{*}{ Variety } & \multicolumn{2}{|c|}{ Conventional barn } & \multicolumn{2}{|c|}{ Plastic shed } \\
\hline & & & Midrib & Lamina & Midrib & Lamina \\
\hline 1997 & Dark air-cured & ITB 1000 & 1.7 & 1.6 & 0.8 & 1.4 \\
\hline 1998 & Dark air-cured & ITB 1000 & 3.3 & 2.9 & 1.9 & 1.6 \\
\hline 1999 & Burley & ITB 501 & 3.3 & 3.1 & 1.7 & 2.4 \\
\hline
\end{tabular}

barns with two to four tiers, and only $20-25 \%$ openings. In agreement with this, results from various trials carried out at ITB show that the concentrations of TSNA in cured leaves are consistently lower after a cure in a plastic shed than in a conventional curing barn (Table 11). In all these experiments the tobacco was stalk-cut and cured as whole plants.

The relationships between $a_{\mathrm{w}}$, nitrite, NN and TSNA concentrations and their changes during curing in the two types of curing barns have been studied in more details in Trial 4 in 2001 (11).

Trial 4: The objectives of this trial were to compare the formation of nitrite and TSNA during air-curing of the burley varieties BB16NN and ITB 501 in two air-curing structures:

- S1: plastic shed, automatically regulated with respect to

RH and temperature and

- S2: traditional curing barn.

To meet this end, 100 stalk-cut plants per variety were hung in the two barns. RH and temperature were recorded every hour. Samples of upper-middle leaves were taken at $\mathrm{H}$, EOY, EOB and EOC for $a_{\mathrm{w}}$ and chemical measurements.
The autumn 2001 was quite dry. RH increased at night up to $95 \%$ and decreased during the daytime to $40-60 \%$. The traditional barn S2 had higher average $\mathrm{RH}$ and a narrower range of variation, $60 \%-90 \%$, than $\mathrm{S} 1$ due to weaker air movement. As in Trial 2, the decline of $a_{\mathrm{w}}$ (Figure 8) was slower in ITB 501 than in BB16NN. In the plastic shed S1, the threshold of 0.9 was crossed at days 16 and 23 in lamina, and at days 34 and 36 in midribs of BB16NN and ITB 501, respectively. These thresholds were reached 4 to 8 days later in the conventional barn $\mathrm{S} 2$.

NN was determined in lamina only. The concentrations increased during yellowing and browning, and then levelled off. In cured lamina, the average NN concentrations were $2.01 \%$ in BB16NN and $0.46 \%$ in ITB 501. The curing environment had no significant effect on the levels of alkaloids. As shown in Tables 12 and 13 and in Figure 9, nitrite was formed in small amounts in lamina in both varieties. Significant concentrations of nitritewere observed only in midribs, and after EOY, especially in the traditional barn S2 (up to $30 \mu \mathrm{g} / \mathrm{g}$ ), whereas much lower concentrations were observed, 6 and $9 \mu \mathrm{g} / \mathrm{g}$ in cured midribs derived from the plastic shed S1. 

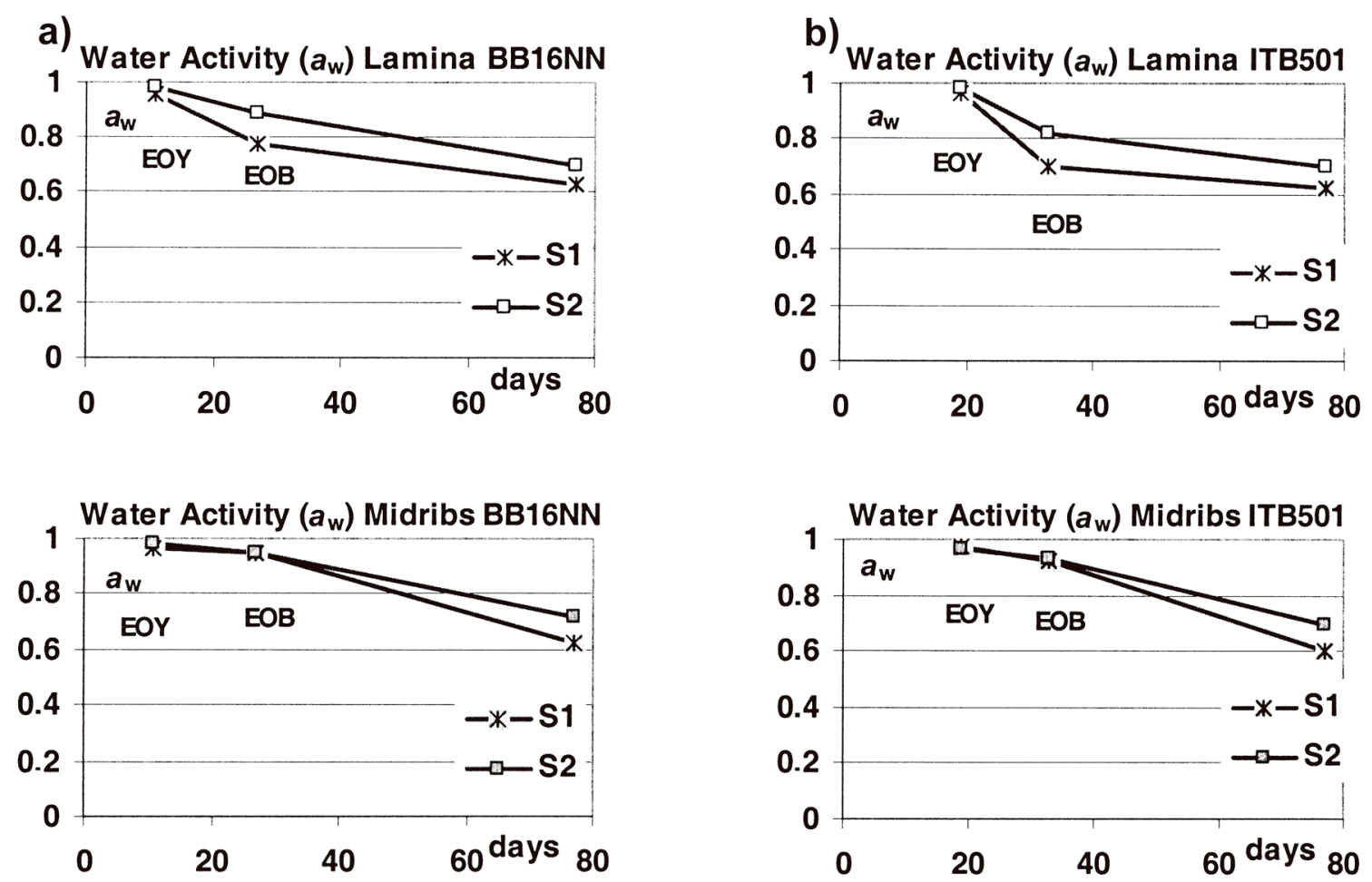

Figure 8. $a_{w}$ Values in lamina and midribs at the end of yellowing (EOY), at the end of browning (EOB) and at the end of curing during air-curing of a) BB16NN and b) ITB 501 in a plastic shed (S1) and in a conventional barn (S2) (Trial 4 - ITB 2001)

Table 12. Nitrite and TSNA concentrations in lamina and midrib at harvest $(\mathrm{H})$, at the end of yellowing (EOY), at the end of browning (EOB) and at the end of curing (EOC) during aircuring of BB16NN in a plastic shed and in a conventional barn (Trial 4 - ITB 2001) ${ }^{\mathrm{a}}$

\begin{tabular}{lcccccc}
\hline \multirow{2}{*}{ BB16NN } & & \multicolumn{2}{c|}{ Plastic shed } & \multicolumn{2}{c}{ Conventional barn } \\
\cline { 3 - 6 } & & Lamina & Midrib & Lamina & Midrib \\
\hline Nitrite & H & 1 & nd & 1 & 1 \\
$(\mu \mathrm{g} / \mathrm{g})$ & EOY & 1 & nd & 1 & 1 \\
& EOB & 2 & 2 & 2 & 3 \\
& EOC & 1 & 6 & 1 & 29 \\
TSNA & H & 0.3 & nd & nd & nd \\
$(\mu \mathrm{g} / \mathrm{g})$ & EOY & 0.3 & nd & 0.4 & nd \\
& EOB & 0.6 & 0.1 & 0.7 & 0.3 \\
& EOC & 1.1 & 1.1 & 1.5 & 3.9 \\
\hline
\end{tabular}

${ }^{a}$ nd: not detected.

In both curing structures, nitrite was formed at higher concentrations in midribs of ITB 501 than in midribs of BB16NN. The concentrations were therefore quite consistent with the changes of the $a_{\mathrm{w}}$ values. The concentrations of TSNA in lamina and midribs of both varieties are presented in Figure 10 and Tables 12 and 13. It can be concluded that like nitrite, TSNA started to accumulate after EOY.

The TSNA concentrations in cured lamina were lower in the plastic shed (S1) than in the conventional barn (S2) for both varieties, 1.1 vs. $1.5 \mu \mathrm{g} / \mathrm{g}$ for BB16NN and $0.5 \mathrm{vs} .1 .0 \mu \mathrm{g} / \mathrm{g}$ for ITB 501. They were slightly higher in midribs of ITB $501,2.1 \mu \mathrm{g} / \mathrm{g}$ in $\mathrm{S} 1$ and $1.7 \mu \mathrm{g} / \mathrm{g}$ in $\mathrm{S} 2$, than in lamina, which is consistent with the higher nitrite concentrations. The TSNA concentrations were low in midribs of BB16NN cured in the plastic shed (S1), $1.1 \mu \mathrm{g} / \mathrm{g}$, and were the highest in midribs of BB16NN cured in the traditional barn S2, $3.9 \mu \mathrm{g} / \mathrm{g}$.
Table 13. Nitrite and TSNA concentrations in lamina and midrib at harvest $(\mathrm{H})$, at the end of yellowing (EOY), at the end of browning (EOB) and at the end of curing (EOC) during aircuring of ITB 501 in a plastic shed and in a conventional barn (Trial 4 - ITB 2001) ${ }^{\text {a }}$

\begin{tabular}{lc|c|c|c|c}
\hline \multirow{2}{*}{ ITB 501 } & & \multicolumn{2}{c|}{ Plastic shed } & \multicolumn{2}{c}{ Conventional barn } \\
\cline { 3 - 6 } & & Lamina & Midrib & Lamina & Midrib \\
\hline Nitrite & H & nd & nd & nd & nd \\
$(\mu \mathrm{g} / \mathrm{g})$ & EOY & 1 & nd & 1 & 2 \\
& EOB & 1 & 15 & 2 & 31 \\
& EOC & 1 & 9 & 1 & 26 \\
TSNA & H & nd & nd & nd & nd \\
$(\mu \mathrm{g} / \mathrm{g})$ & EOY & nd & nd & nd & nd \\
& EOB & nd & 0.9 & 0.4 & 1.7 \\
& EOC & 0.5 & 2.1 & 1.0 & 1.7 \\
\hline
\end{tabular}

${ }^{\mathrm{a}} \mathrm{nd}=$ not detected

A comparison of TSNA concentrations in midribs of BB16NN and ITB 501 cured in the traditional barn S2 indicates again that a comparable high nitrite concentration results in higher TSNA concentrations in a converter than in a non-converter variety.

c) Effect of curing temperature: In Trial 5 carried out in 1997, several stalk-cut plants (WP) or primed upper middle leaves (PL) of the dark air-cured variety ITB 1000 were cured in different curing structures, with varied conditions of temperature and $\mathrm{RH}$, resulting in seven different treatments.

- T1: air-curing in a conventional curing barn.

- T2: air-curing in a plastic shed.

- T3: curing in a bulk-curing barn heated with a direct flame burner (DFBCB). Stem drying (SD) at $25-27^{\circ} \mathrm{C}$.

- T4: curing in a bulk-curing barn heated with a direct flame burner (DFBCB). Stem drying at $70{ }^{\circ} \mathrm{C}$. 

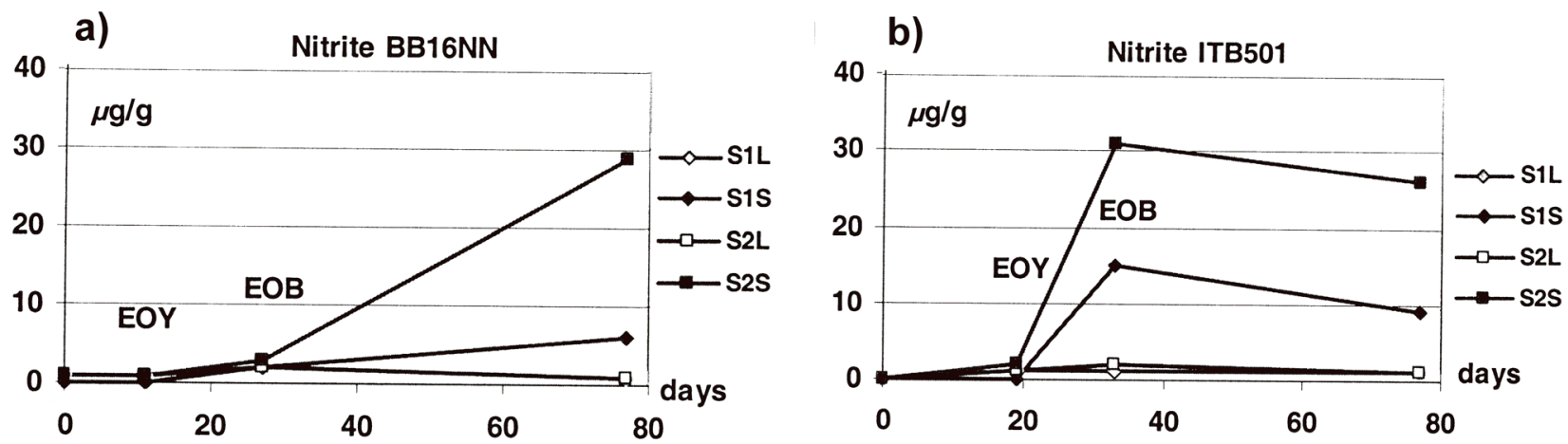

Figure 9. Concentrations of nitrite in lamina (L) and midrib (S) at harvest, at the end of yellowing (EOY), at the end of browning (EOB) and at the end of curing during air-curing of a) BB16NN and b) ITB 501 in a plastic shed (S1) and in a conventional barn (S2) (Trial 4 - ITB 2001)

a)

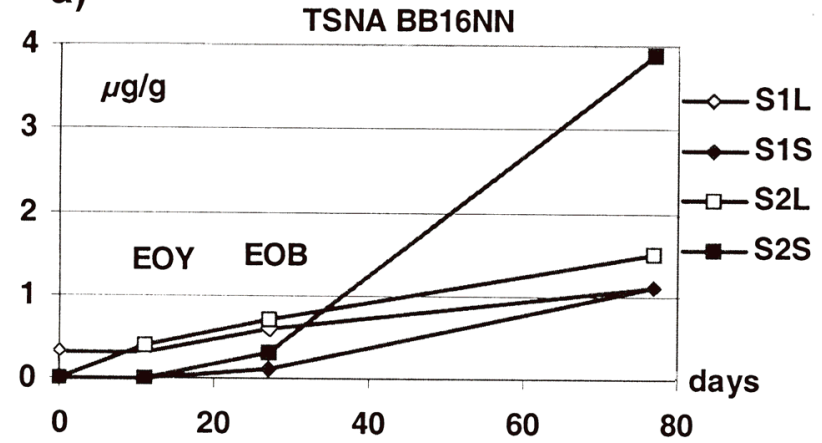

b)

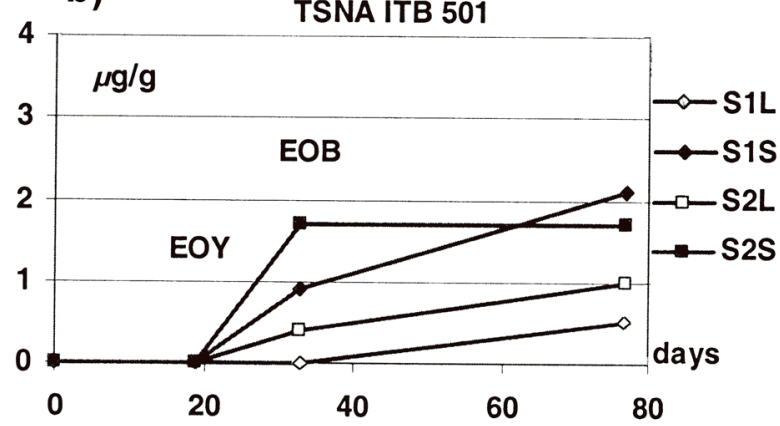

Figure 10. Concentrations of TSNA in lamina (L) and midrib (S) at harvest, at the end of yellowing (EOY), at the end of browning (EOB) and at the end of curing during air-curing of a) BB16NN and b) ITB 501in a plastic shed (S1) and in a conventional barn (S2) (Trial 4 - ITB 2001)

Table 14. TSNA concentrations in lamina and midribs of primed leaves (PL) and leaves from stalk-cut plants (WP) of ITB 1000 after curing under different conditions of temperature and $\mathrm{RH}$ at yellowing ( $\mathrm{Y}$ ), browning (B) and stem-drying (SD), and in different curing environments: conventional barn, plastic shed, direct flame bulk-curing barn (DFBCB), conditioned room and electrically heated bulk-curing barn (EBCB) (Trial 5 - ITB 1997)

\begin{tabular}{|c|c|c|c|c|c|c|c|c|c|c|}
\hline \multirow{2}{*}{\multicolumn{2}{|c|}{ Treatment }} & \multirow[b]{2}{*}{ Curing barn } & \multicolumn{3}{|c|}{ Temperature $\left({ }^{\circ} \mathrm{C}\right)$} & \multicolumn{3}{|c|}{ Relative humidity (\%) } & \multicolumn{2}{|c|}{ TNSA $(\mu \mathrm{g} / \mathrm{g})$} \\
\hline & & & $Y$ & $\mathrm{~B}$ & SD & $Y$ & $\mathrm{~B}$ & SD & Midrib & Lamina \\
\hline $\mathrm{T} 1$ & WP & conventional & $14 / 25$ & $18 / 23$ & $10 / 23$ & $55-85$ & $70-90$ & $70-90$ & 1.7 & 1.6 \\
\hline T2 & WP & plastic shed & $20 / 40$ & $20 / 35$ & $15 / 30$ & $45-70$ & $45-70$ & $45-60$ & 0.8 & 1.4 \\
\hline T3 & WP & DFBCB & $25 / 27$ & $25 / 27$ & $25 / 27$ & $80-100$ & $55-85$ & $40-80$ & 1.7 & 4.1 \\
\hline $\mathrm{T} 4$ & WP & DFBCB & $25 / 27$ & $25 / 27$ & 70 & $80-100$ & $55-85$ & $20-55$ & 1.2 & 33.4 \\
\hline T5 & $P L$ & $\begin{array}{c}\text { cond. room + } \\
\text { EBCB }\end{array}$ & $25 / 27$ & $14 / 16$ & 70 & $80-85$ & 70 & $20-55$ & 3.5 & 2.7 \\
\hline T6 & $\mathrm{PL}$ & $\begin{array}{c}\text { cond. room + } \\
\text { EBCB }\end{array}$ & $25 / 27$ & $25 / 27$ & 70 & $80-85$ & 70 & $20-55$ & 14.3 & 5.0 \\
\hline T7 & PL & $\begin{array}{l}\text { cond. room + } \\
\text { EBCB }\end{array}$ & $25 / 27$ & $35 / 37$ & 70 & $80-85$ & 70 & $20-55$ & 28.5 & 4.9 \\
\hline
\end{tabular}

- T5: yellowing $\left(25-27^{\circ} \mathrm{C}\right)$ and browning $\left(14-16^{\circ} \mathrm{C}\right)$ in a conditioned room, then stem drying at $70{ }^{\circ} \mathrm{C}$ in an electrically heated bulk-curing barn (EBCB).

- T6: yellowing and browning $\left(25-27^{\circ} \mathrm{C}\right)$ in a conditioned room, then stem drying at $70{ }^{\circ} \mathrm{C}$ in an electrically heated bulk-curing barn (EBCB).

- T7 : yellowing $\left(25-27^{\circ} \mathrm{C}\right)$ and browning $\left(35-37^{\circ} \mathrm{C}\right)$ in a conditioned room, then stem drying at $70{ }^{\circ} \mathrm{C}$ in an electrically heated bulk-curing barn (EBCB).

It can be concluded from the results listed in Table 14 that curing in a plastic shed resulted in lower TSNA values than curing in a conventional curing barn (see T1 and T2). Leaves that had been cured in a bulk-curing barn heated with the direct flame burner (T3, T4) had higher TSNA concentrations due to gas-phase nitrosation than leaves that were air-cured. This effect was most evident in lamina due to the higher concentration of precursor alkaloids. It can also be concluded that higher temperature at stem drying, i.e. longer working time of the burner and hence higher delivery of nitrogen oxides gave higher concentrations of TSNA in lamina (6). This result should also be attributed to a higher nitrosation rate at the higher temperature. 
Table 15. Effect of curing temperature and RH at yellowing $(Y)$, browning $(B)$ and stem-drying (SD) on TSNA concentrations in cured midrib and lamina of primed leaves (PL) of ITB 1000 (Trial 6 - ITB 1998)

\begin{tabular}{|c|c|c|c|c|c|c|c|c|c|c|}
\hline \multirow{2}{*}{\multicolumn{2}{|c|}{ Treatment }} & \multirow[b]{2}{*}{ Curing barn } & \multicolumn{3}{|c|}{ Temperature $\left({ }^{\circ} \mathrm{C}\right)$} & \multicolumn{3}{|c|}{ Relative humidity (\%) } & \multicolumn{2}{|c|}{ TNSA $(\mu \mathrm{g} / \mathrm{g})$} \\
\hline & & & $Y$ & $\mathrm{~B}$ & S.D. & $Y$ & $\mathrm{~B}$ & SD & Midrib & Lamina \\
\hline T1 & $\mathrm{PL}$ & conventional & $16 / 25$ & $15 / 25$ & $10 / 20$ & $80 / 90$ & $70 / 85$ & $50 / 80$ & 4.4 & 1.9 \\
\hline T2 & PL & cond. room & $25 / 27$ & $14 / 16$ & $14 / 16$ & 80 & 70 & 30 & nd & 1.1 \\
\hline T3 & PL & cond. room & 30 & $14 / 16$ & $14 / 16$ & $65-90$ & 70 & 30 & 0.6 & 1.4 \\
\hline T4 & PL & cond. room & $36 / 38$ & $14 / 16$ & $14 / 16$ & $65-90$ & 70 & 30 & 0.6 & 0.5 \\
\hline
\end{tabular}

${ }^{a}$ nd: not detected.

Table 16. Nitrite and TSNA concentrations in midrib and lamina of cured B217 at the end of curing (ITD: immediate taking down and stripping of tobacco) and after a delayed taking down (DTD: delayed taking down and stripping of tobacco) (Trial 7 - ITB 2003)

\begin{tabular}{|c|c|c|c|c|c|}
\hline \multirow{2}{*}{\multicolumn{2}{|c|}{ Samples }} & \multicolumn{2}{|c|}{ Nitrite $(\mu \mathrm{g} / \mathrm{g})$} & \multicolumn{2}{|c|}{ TSNA $(\mu \mathrm{g} / \mathrm{g})$} \\
\hline & & ITD & DTD & ITD & DTD \\
\hline \multirow{2}{*}{ Cutters } & Lamina & 1.74 & 3.92 & 3.46 & 5.49 \\
\hline & Midrib & 4.57 & 7.28 & 1.57 & 2.19 \\
\hline \multirow[t]{2}{*}{ Leaves } & Lamina & 0.79 & 1.82 & 2.40 & 4.57 \\
\hline & Midrib & 4.77 & 5.78 & 1.69 & 3.79 \\
\hline
\end{tabular}

Comparison of $\mathrm{T} 6$ and $\mathrm{T} 4$, where the same parameters during curing were applied, shows that the TSNA concentrations were much lower in lamina originating from tobacco cured in the electrically heated barn than in lamina from tobacco cured in the barn heated with a direct flame burner. However, in the case of midribs, the TSNA levels were higher in the tobacco cured in the electrically heated barn than in the barn equipped with the direct flame burner. These results may be possibly explained by the fact that the midrib which dries out slower than lamina is more susceptible to differences in ventilation.

The effect of the temperature per se can be observed by a comparison of treatments T5, T6 and T7, in which stem drying was performed in an electrically heated bulk-curing barn. These treatments differed only with respect to the temperature during the browning stage which increased by $10{ }^{\circ} \mathrm{C}$ going from T5 to T7. As shown in Table 14, the TSNA concentrations in the midribs increased dramatically with temperature. A possible explanation is that temperatures such as $25-35{ }^{\circ} \mathrm{C}$ are most favourable for growth of bacteria including those responsible for the production of nitrite during the browning phase. This is most evident in midribs, in which the moisture content remains at an $a_{\mathrm{w}}$ value $>0.9$ for a longer period than in lamina.

An additional indication that low temperatures during browning and stem drying can result in low TSNA concentrations was obtained from Trial 6 carried out in 1998 with primed leaves of the DAC variety ITB 1000 . As can be seen from Table 15, all leaves that have been subjected to low temperatures at browning and stem drying (T2, T3, T4) had lower TSNA concentrations than tobacco from treatment T1, i.e. conventional barn. This effect was independent of the temperature during the yellowing stage. Unfortunately, despite the very low TSNA content, the leaves cured at low temperature were of very poor quality.
Formation of TSNA in cured tobacco between the end of cure and stripping

Trial 7: In 2003, Trial 7 was carried out at ITB with the objectives of measuring the effects of a delayed taking down and stripping on nitrite and TSNA concentrations in cured leaves. The burley variety B217 was chosen for its high level of NN conversion. The experiment involved 200 stalk-cut plants, which were cured in a plastic shed. One hundred of these were taken down and stripped as soon as the cure was completed (immediate taking down and stripping: ITD). Two samples of cutters and upper middle leaves were split into lamina and midribs. The samples were stored at $-18^{\circ} \mathrm{C}$ until the end of the trial. The remaining 100 plants were kept hanging in the barn for 21 days, where they underwent natural climatic fluctuations: 5 days at $80-90 \%$ RH, 1 day at $40-70 \%, 6$ days at $85-95 \%, 2$ days at $40-50 \%, 2$ days at $85-90 \%$ and 5 days at 35-50\%. After this period of delayed taking down and stripping (DTD), two samples of cutters and upper middle leaves were processed as described above.

The results compiled in Table 16 show that, after 21 days of prolonged hanging in the barn in alternate dry and humid conditions, the nitrite concentrations increased by $20-60 \%$ in midribs, and by $125-130 \%$ in lamina. The corresponding increases of TSNA were $40-125 \%$ and $60-90 \%$, respectively. The fact that the nitrite concentrations increased may be an indication that nitrate-reducing microorganisms were still active during this period.

\section{Variability of TSNA concentrations in cured tobacco among growers' crops}

In 2001, 2002 and 2003, samples of cured tobacco leaves from the upper middle stalk position were collected from several barns in the Bergerac area immediately after curing. The burley variety BB16A was the same among the growers, and the soils, the climatic conditions and the agricultural practices were similar. The main variable factors were conditions of curing. The results of chemical analyses and quality evaluation (2003) are shown in Tables 17-19. A summary of the results is presented in Table 20. The concentrations of nicotine, NN, TSNA and the ratios of NN/total alkaloids in cured lamina varied significantly between years and, within the same year, between barns. The results presented in Table 19 show that midribs had generally much higher NN/total alkaloids ratios, as well as nitrite and TSNA concentrations than lamina. The high TSNA concentrations in midribs were generally correlated with high TSNA concentrations in lamina $\left(R^{2}=0.77\right)$. It is 
Table 17. Growers curing survey-nicotine, NN, total alkaloids, TSNA concentrations and NN/total alkaloids ratios (NN/Alk) in lamina of cured leaves of BB16A. Samples collected in 2001 in the area of Bergerac.

\begin{tabular}{|c|c|c|c|c|c|}
\hline No. of barn 2001 & Nicotine (\%) & NN (\%) & Total alkaloids (\%) & NN/Alk (\%) & TSNA $(\mu \mathrm{g} / \mathrm{g})$ \\
\hline 1 & 3.25 & 0.24 & 3.69 & 7 & 1.98 \\
\hline 2 & 3.79 & 0.16 & 4.13 & 4 & 0.81 \\
\hline 3 & 4.97 & 0.34 & 5.65 & 6 & 2.24 \\
\hline 4 & 4.53 & 0.33 & 5.18 & 6 & 1.01 \\
\hline 5 & 4.60 & 0.31 & 5.24 & 6 & 27.99 \\
\hline 6 & 3.35 & 0.13 & 3.66 & 3 & 1.04 \\
\hline 7 & 4.46 & 0.53 & 5.33 & 10 & 3.89 \\
\hline
\end{tabular}

Table 18. Growers curing survey - nicotine, NN, total alkaloids, TSNA concentrations and NN/total alkaloids ratios (NN/Alk) in lamina of cured leaves of BB16A. Samples collected in 2002 in the area of Bergerac.

\begin{tabular}{l|c|c|c|c|cc}
\hline No. of barn 2002 & $\begin{array}{c}\text { Nicotine (\%) } \\
\text { (Lamina) }\end{array}$ & $\begin{array}{c}\text { NN (\%) } \\
\text { (Lamina) }\end{array}$ & $\begin{array}{c}\text { Total alkaloids (\%) } \\
\text { (Lamina) }\end{array}$ & $\begin{array}{c}\text { NN/Alk (\%) } \\
(\text { Lamina) }\end{array}$ & $\begin{array}{c}\text { TSNA }(\mu \mathrm{g} / \mathrm{g}) \\
(\text { Lamina })\end{array}$ & $\begin{array}{c}\text { TSNA } \mu \mathrm{g} / \mathrm{g} \\
(\text { Midrib) }\end{array}$ \\
\hline 1 & 2.93 & 0.49 & 3.52 & 14 & 0.52 & 0.59 \\
2 & 3.24 & 2.37 & 5.83 & 41 & 2.95 & 3.93 \\
3 & 3.55 & 0.67 & 4.38 & 15 & 1.07 & 4.07 \\
4 & 3.31 & 0.45 & 3.89 & 11 & 1.67 & 6.27 \\
5 & 4.41 & 0.60 & 5.20 & 12 & 2.26 & 6.74 \\
6 & 4.57 & 0.22 & 4.95 & 5 & 0.76 & 1.84 \\
7 & 4.09 & 1.11 & 5.41 & 20 & 2.37 & 1.43 \\
8 & 6.79 & 0.59 & 7.65 & 8 & 1.65 & 0.73 \\
9 & 4.82 & 0.55 & 5.55 & 10 & 0.99 & 0.98 \\
10 & 3.88 & 1.14 & 5.23 & 22 & 2.12 & 7.73 \\
\hline
\end{tabular}

Table 19. Growers curing survey - nicotine, NN, total alkaloids, nitrite, TSNA concentrations and NN/total alkaloids ratios (NN/Alk) in cured lamina and midrib and Quality Index of cured leaves of BB16A. Samples collected in 2003 in the area of Bergerac.

\begin{tabular}{|c|c|c|c|c|c|c|c|c|c|c|c|c|c|}
\hline \multirow[b]{2}{*}{$\begin{array}{l}\text { No. of barn } \\
2003^{\text {a }}\end{array}$} & \multicolumn{6}{|c|}{ Lamina } & \multirow[b]{2}{*}{$\begin{array}{c}\text { Quality } \\
\text { index }(0-5)\end{array}$} & \multicolumn{6}{|c|}{ Midrib } \\
\hline & \begin{tabular}{|c|}
$\begin{array}{c}\text { Nicotine } \\
(\%)\end{array}$ \\
\end{tabular} & $\begin{array}{l}\mathrm{NN} \\
(\%) \\
\end{array}$ & \begin{tabular}{|c|}
$\begin{array}{c}\text { Total Alk } \\
(\%)\end{array}$ \\
\end{tabular} & $\begin{array}{c}\text { NN/Alk } \\
(\%)\end{array}$ & $\begin{array}{l}\text { Nitrite } \\
(\mu \mathrm{g} / \mathrm{g})\end{array}$ & $\begin{array}{l}\text { TSNA } \\
(\mu \mathrm{g} / \mathrm{g}) \\
\end{array}$ & & \begin{tabular}{|c|}
$\begin{array}{c}\text { Nicotine } \\
(\%)\end{array}$ \\
\end{tabular} & $\begin{array}{l}\mathrm{NN} \\
(\%)\end{array}$ & $\begin{array}{c}\text { Total Alk } \\
(\%)\end{array}$ & \begin{tabular}{|c|} 
NN/Alk \\
$(\%)$
\end{tabular} & $\begin{array}{l}\text { Nitrite } \\
(\mu \mathrm{g} / \mathrm{g})\end{array}$ & $\begin{array}{l}\text { TSNA } \\
(\mu \mathrm{g} / \mathrm{g})\end{array}$ \\
\hline 1-R1 & 3.74 & 0.15 & 4.03 & 4 & 0.9 & 0.76 & 1.5 & 0.57 & 0.04 & 0.64 & 7 & 2.0 & 0.28 \\
\hline 1-R2 & 4.26 & 0.27 & 4.71 & 6 & 0.5 & 0.75 & 2.0 & 0.52 & 0.16 & 0.71 & 23 & 1.5 & 0.00 \\
\hline 2-R1 & 4.87 & 0.25 & 5.29 & 5 & 0.5 & 0.71 & 2.5 & 0.57 & 0.14 & 0.73 & 19 & 7.2 & 0.25 \\
\hline 2-R2 & 5.05 & 0.24 & 5.48 & 4 & 0.8 & 0.72 & 1.4 & 0.60 & 0.14 & 0.76 & 19 & 37.8 & 2.23 \\
\hline 3-R1 & 5.62 & 0.46 & 6.44 & 7 & 2.1 & 2.08 & 4.0 & 0.73 & 0.23 & 0.99 & 23 & 105.1 & 5.68 \\
\hline 3-R2 & 5.70 & 0.58 & 6.65 & 9 & 1.9 & 2.30 & 2.5 & 0.71 & 0.28 & 1.02 & 27 & 145.9 & 9.82 \\
\hline 4-R1 & 4.32 & 0.44 & 4.98 & 9 & 1.9 & 2.36 & 3.0 & 0.58 & 0.16 & 0.76 & 21 & 118.4 & 6.53 \\
\hline 4-R2 & 4.36 & 0.35 & 4.93 & 7 & 1.0 & 0.85 & 3.0 & 0.52 & 0.18 & 0.72 & 25 & 21.2 & 2.30 \\
\hline 5-R1 & 5.92 & 0.26 & 6.55 & 4 & 1.9 & 1.78 & 4.0 & 1.02 & 0.19 & 1.26 & 15 & 27.1 & 2.32 \\
\hline 5-R2 & 5.64 & 0.30 & 6.26 & 5 & 2.1 & 2.26 & 3.5 & 0.85 & 0.22 & 1.10 & 20 & 131.3 & 7.95 \\
\hline 6-R1 & 5.83 & 0.43 & 6.62 & 7 & 0.7 & 1.18 & 4.5 & 0.98 & 0.17 & 1.19 & 14 & 24.5 & 4.02 \\
\hline 6-R2 & 5.98 & 0.55 & 6.93 & 8 & 1.8 & 1.63 & 4.0 & 1.01 & 0.28 & 1.33 & 21 & 74.1 & 7.46 \\
\hline 7-R1 & 5.50 & 0.23 & 6.05 & 4 & 2.9 & 0.93 & 4.0 & 1.02 & 0.18 & 1.25 & 15 & 55.4 & 1.72 \\
\hline 7-R2 & 5.24 & 0.29 & 5.83 & 5 & 1.5 & 0.89 & 3.5 & 0.88 & 0.21 & 1.14 & 19 & 20.4 & 2.06 \\
\hline
\end{tabular}

${ }^{a} \mathrm{R} 1, \mathrm{R} 2$ = 2 samples per barn, $1 \mathrm{~m}$ apart.

Table 20. Growers curing survey - range of NN, TSNA concentrations and NN/total alkaloids ratios (NN/Alk) in cured lamina of BB16A. Samples collected in $2001(n=5), 2002(n=9)$, and $2003(n=14)$ in the area of Bergerac.

\begin{tabular}{l|c|c|c|c|c|c|c|c|c}
\hline \multirow{2}{*}{ Samples } & \multicolumn{3}{c|}{ NN (\%) } & \multicolumn{3}{c}{ NN/Alk (\%) } & \multicolumn{3}{c}{ TSNA $(\mu / \mathrm{g})$} \\
\cline { 2 - 10 } & Minimum & Maximum & Average & Minimum & Maximum & Average & Minimum & Maximum & Average \\
\hline 2001 & 0.13 & 0.34 & 0.29 & 3 & 10 & 6 & 0.8 & 3.9 & 1.83 \\
2002 & 0.22 & 1.14 & 0.65 & 5 & 22 & 13 & 0.5 & 3.0 & 1.64 \\
2003 & 0.15 & 0.58 & 0.34 & 4 & 9 & 6 & 0.7 & 2.4 & 1.37 \\
\hline
\end{tabular}


Table 21. Growers storage survey - nicotine, NN, total alkaloids, nitrite, TSNA concentrations, NN/total alkaloids ratios (NN/Alk) and moisture content in cured strips and stems after storage and threshing of cured BB16A. Samples collected in 2003 in the area of Bergerac.

\begin{tabular}{l|c|c|c|c|c|c|c|c|c|c|c|c|c|c|}
\hline \multirow{2}{*}{$\begin{array}{l}\text { No. of barn } \\
2003\end{array}$} & $\begin{array}{c}\text { Nicotine } \\
(\%)\end{array}$ & $\begin{array}{c}\text { NN } \\
(\%)\end{array}$ & $\begin{array}{c}\text { Total Alk } \\
(\%)\end{array}$ & $\begin{array}{c}\text { NN/Alk } \\
(\%)\end{array}$ & $\begin{array}{c}\text { Nitrite } \\
(\mu \mathrm{g} / \mathrm{g})\end{array}$ & $\begin{array}{c}\text { TSNA } \\
(\mu \mathrm{g} / \mathrm{g})\end{array}$ & $\begin{array}{c}\text { Moisture } \\
\text { content }(\%)\end{array}$ & $\begin{array}{c}\text { Nicotine } \\
(\%)\end{array}$ & $\begin{array}{c}\text { NN } \\
(\%)\end{array}$ & $\begin{array}{c}\text { Total Alk } \\
(\%)\end{array}$ & $\begin{array}{c}\text { NN/Alk } \\
(\%)\end{array}$ & $\begin{array}{l}\text { Nitrite } \\
(\mu \mathrm{g} / \mathrm{g})\end{array}$ & $\begin{array}{c}\text { TSNA } \\
(\mu \mathrm{g} / \mathrm{g})\end{array}$ & $\begin{array}{c}\text { Moisture } \\
\mathrm{content}(\%)\end{array}$ \\
\hline 1 & 4.23 & 0.16 & 4.56 & 3.5 & 0.96 & 1.44 & 19.3 & 0.73 & 0.09 & 0.85 & 10.6 & 2.21 & 1.23 & 23.5 \\
2 & 4.64 & 0.20 & 5.02 & 3.9 & 0.75 & 1.06 & 17.6 & 0.62 & 0.10 & 0.74 & 13.0 & 4.84 & 2.07 & 23.3 \\
3 & 4.65 & 0.41 & 5.36 & 7.6 & 2.22 & 3.04 & 17.9 & 0.57 & 0.19 & 0.78 & 24.5 & 31.89 & 11.42 & 18.9 \\
4 & 3.68 & 0.32 & 4.20 & 7.6 & 2.59 & 2.54 & 15.4 & 0.49 & 0.10 & 0.61 & 16.5 & 29.63 & 6.39 & 19.7 \\
5 & 5.24 & 0.27 & 5.84 & 4.6 & 1.25 & 2.55 & 20.7 & 1.10 & 0.17 & 1.32 & 12.8 & 9.60 & 6.70 & 23.9 \\
6 & 5.01 & 0.21 & 5.55 & 3.8 & 1.97 & 2.69 & 23.7 & 1.75 & 0.13 & 1.95 & 6.5 & 22.10 & 6.56 & 24.7 \\
7 & 4.57 & 0.20 & 5.03 & 4.0 & 1.20 & 2.13 & 22.1 & 1.56 & 0.15 & 1.79 & 8.6 & 10.07 & 4.83 & 25.6 \\
\hline
\end{tabular}

Table 22. Growers storage survey - concentrations of nicotine, NN, total alkaloids, nitrite, TSNA and the ratio of NN/total alkaloids (NN/Alk) in whole leaves before and after on-farm storage. Samples collected in 2003 in the area of Bergerac.

\begin{tabular}{|c|c|c|c|c|c|c|c|c|c|c|c|c|}
\hline \multirow[b]{2}{*}{$\begin{array}{l}\text { No. of barn } \\
2003\end{array}$} & \multicolumn{6}{|c|}{ Whole leaf at taking down (means of 2 repetitions) } & \multicolumn{6}{|c|}{ Whole leaf after storage (1 repetition for TSNA) } \\
\hline & \begin{tabular}{|c|}
$\begin{array}{c}\text { Nicotine } \\
(\%)\end{array}$ \\
\end{tabular} & $\begin{array}{l}\mathrm{NN} \\
(\%)\end{array}$ & \begin{tabular}{|c|}
$\begin{array}{c}\text { Total Alk } \\
(\%)\end{array}$ \\
\end{tabular} & $\begin{array}{c}\text { NN/Alk } \\
(\%)\end{array}$ & $\begin{array}{l}\text { Nitrite } \\
(\mu \mathrm{g} / \mathrm{g})\end{array}$ & $\begin{array}{l}\text { TSNA } \\
(\mu \mathrm{g} / \mathrm{g}) \\
\end{array}$ & \begin{tabular}{|c|}
$\begin{array}{c}\text { Nicotine } \\
(\%)\end{array}$ \\
\end{tabular} & $\begin{array}{l}\mathrm{NN} \\
(\%)\end{array}$ & \begin{tabular}{|c|}
$\begin{array}{c}\text { Total Alk } \\
(\%)\end{array}$ \\
\end{tabular} & $\begin{array}{c}\text { NN/Alk } \\
(\%)\end{array}$ & $\begin{array}{l}\text { Nitrite } \\
(\mu \mathrm{g} / \mathrm{g})\end{array}$ & $\begin{array}{l}\text { TSNA } \\
(\mu \mathrm{g} / \mathrm{g}) \\
\end{array}$ \\
\hline 1 & 3.03 & 0.18 & 3.33 & 5.3 & 1.01 & 0.58 & 3.44 & 0.14 & 3.73 & 3.9 & 1.32 & 1.39 \\
\hline 2 & 3.78 & 0.21 & 4.13 & 5.2 & 6.45 & 0.85 & 3.74 & 0.17 & 4.07 & 4.3 & 1.86 & 1.28 \\
\hline 3 & 4.30 & 0.45 & 5.02 & 8.9 & 35.95 & 3.72 & 3.51 & 0.35 & 4.09 & 8.5 & 10.37 & 5.37 \\
\hline 4 & 3.23 & 0.33 & 3.72 & 8.9 & 21.41 & 2.43 & 2.95 & 0.27 & 3.38 & 8.0 & 10.49 & 3.41 \\
\hline 5 & 4.31 & 0.26 & 4.81 & 5.3 & 25.49 & 2.97 & 4.16 & 0.24 & 4.66 & 5.2 & 3.80 & 3.63 \\
\hline 6 & 4.47 & 0.41 & 5.16 & 8.0 & 15.34 & 2.67 & 4.24 & 0.19 & 4.70 & 4.1 & 7.86 & 3.61 \\
\hline 7 & 4.07 & 0.24 & 4.55 & 5.3 & 12.46 & 1.20 & 3.76 & 0.19 & 4.17 & 4.5 & 3.79 & 2.85 \\
\hline \multicolumn{7}{|c|}{ Average evolution during storage } & $-5 \%$ & $-25 \%$ & $-6 \%$ & $-18 \%$ & $-67 \%$ & $+50 \%$ \\
\hline
\end{tabular}

also evident from Table 19 that the highest Quality Indices were linked to medium TSNA concentrations. The leaves that had either very low or the highest TSNA concentrations were of poor or of medium quality. The former had been cured too fast and had a yellowish coloration, whereas the latter were dull and damaged with "houseburn" (i.e.: barn rot and/or fermentation).

\section{Formation of TSNA in bales of cured tobacco between stripping and delivery}

The curing survey carried out in 2003 (results in Table 19) also included a study on possible changes of TSNA concentrations during storage at the farm level from stripping/baling to delivery. The duration of the storage, either as regular bales of about $25 \mathrm{~kg}$, or as small temporary bales of about $10 \mathrm{~kg}$, was approximately three months. The bales under study were made with the upper-middle leaves stripped from the whole plants that surrounded the two dataloggers placed in the barn during curing. The bales were placed in the barns on wooden boards or plastic sheets as insulating material. At the time of delivery, representative samples of leaves $(5.0$ to $7.5 \mathrm{~kg}$ ) were taken from the bales and threshed in a Cardwell thresher to separate strips and stems. Samples were taken for the determination of moisture, individual alkaloids, nitrite (2 replications) and TSNA (1 replication).

From a comparison of the data shown in Tables 19 and 21, it can be concluded that the TSNA concentrations increased systematically during the storage in both lamina and stems, whereas the nitrite concentrations decreased in stems.
The separation of lamina and midrib was not performed the same way, i.e. by hand cutting for samples at stripping and by threshing for samples after storage. Therefore, the only valid comparison has to be made at a whole leaf basis taking into account the midrib/whole leaf ratios at the two sampling times. The results of the calculation are shown in Table 22. On a whole leaf basis, the concentrations of total alkaloids, nicotine and NN decreased during storage. Since the decrease of the NN concentrations was larger than that of nicotine, the ratio of NN/total alkaloids also decreased. Nitrite concentrations decreased strongly, by $67 \%$ on average, up to $88 \%$, an effect that may be accounted for by chemical reactions, volatilization and decomposition. By contrast, the concentrations of TSNA increased by $22 \%$ to $140 \%$ in individual samples, and by $49.5 \%$ on average. This increase may be rationalised by chemical reactions between alkaloids and the residual nitrite and also between alkaloids and various transnitrosating species that had been formed during curing. There is no evidence that nitrate-reducing microorganisms played a role during storage.

\section{CONCLUSIONS}

Freshly harvested leaves contain virtually no nitrite and no TSNA, whereas TSNA are found in tobacco products. A significant proportion and, very likely, the majority of the TSNA that are present in processed tobacco are generated at the farm level, i.e. during curing, a delayed stripping and storage. The amount of TSNA formed at the farm level depends on numerous factors which breeders and growers may be able to modify. 
The propensity of the variety to convert nicotine into NN must be taken into account by the breeders as a first priority, because the same nitrite concentration gives rise to higher levels of TSNA in leaves containing high concentrations of $\mathrm{NN}$ than in leaves of a non-converter variety. However, to control NN conversion is a difficult task, owing to the genetic instability of this trait, especially in burley varieties. In breeding programmes, the ratio of NN/total alkaloids in midribs of cured leaves may be a valuable tool in screening of varieties. Though the agricultural practices have an effect on the level of alkaloids in leaves, it seems that the grower has no means to modify the level of conversion during curing. Another target for the breeders is to create varieties with a rapid rate of water loss from the leaf during curing, as this will shorten the length of time during which the nitrate from disintegrated cells is available to the nitrate-reducing microorganisms. We cannot prevent the midribs from losing water slower than lamina, and to form more nitrite. Although the burley tobaccos are known to lose water slower than some other types, our results show that some burley varieties have a faster $a_{\mathrm{w}}$ decrease than others and, therefore, produce less nitrite.

On the grower's side, all agricultural practices that increase alkaloid concentrations also increase the concentrations of TSNA. This is not only because the alkaloids are direct precursors of TSNA, but also because some practices, such as low topping and high nitrogen fertilization, increase the thickness of leaf tissues and, therefore, slow down the rate of the curing.

The type of harvest has an effect on the rate of curing and, therefore, on the concentrations of nitrite and TSNA in cured tobaccos. However, even if primed leaves contain generally lower levels of TSNA than stalk-cut plants, the latter type of harvest yields, under the French conditions, cured leaves of better quality.

Ventilation plays a key role on parameters such as relative humidity, temperature, and air movement which influence water activity, microbial growth, access to aerobic conditions and removal of gases. For these reasons, the leaves cured in a highly ventilated plastic shed usually contain smaller amounts of TSNA than leaves cured in a conventional curing-barn.

Microbial populations responsible for the formation of nitrite may grow in cured tobacco, and TSNA concentrations may increase, if the leaves are kept hanging in the barn under humid conditions after the end of cure. Furthermore, TSNA may continue to be formed by chemical reaction in bales or batches of leaves during the time period between stripping and delivery. It is likely that the level of residual nitrite in cured tobacco and temperature play a major role in the reaction. For these reasons, it should be recommended to the growers to take down and strip the tobacco as soon as it is cured, and to deliver the cured leaves as soon as possible, so that threshing and processing are quickly implemented.

French climatic conditions, with moderate temperatures and relative humidity during the curing period, allow the production of air-cured tobaccos that have both good quality and low TSNA concentrations. Efforts made by the breeders, particularly with respect to $\mathrm{NN}$ levels, and vigilance on the growers' part, with respect to cultivation, type of barn, curing management and storage, should contribute to maintaining this favourable situation.

\section{REFERENCES}

1. Hoffmann, D. and S. Hecht: Nicotine-derived $N$ nitrosamines and tobacco-related cancer: Current status and future directions; Cancer Res. 45 (1985) 435-444.

2. Burton, H.R., L.P. Bush, and J.L. Hamilton: Effect of curing on the chemical composition of burley tobacco; Recent Adv. Tob. Sci. 9 (1983) 91-153.

3. Burton, H.R., G.H. Childs, R.A. Andersen, and P.D. Fleming: Changes in chemical composition of Burley tobacco during senescence and curing. 3. Tobacco specific nitrosamines; J. Agric. Food Chem. 37 (1989) 426-430.

4. Wiernik, A., A. Christakopoulos, L. Johansson, and I. Wahlberg: Effect of air-curing on chemical composition of tobacco; Recent Adv. Tob. Sci. 21 (1995) 39-80.

5. Bush, L.P., M. Cui, H. Shi, H.R. Burton, F.F. Fannin, L. Lei, and N. Dye: Formation of tobacco specific nitrosamines in air-cured tobacco; Recent Adv. Tob. Sci. 27 (2001) 23-46.

6. Nestor, T.B., J.S. Gentry, D.M. Peele, M.G. Riddick, B.T. Conner, and M.E. Edwards: Role of oxides of nitrogen in tobacco-specific nitrosamine formation in flue-cured tobacco; Beitr. Tabakforsch. Int. 20 (2003) 467-475.

7. Morin, A., A. Porter, A. Ratavicius, and J. Joly: Evolution of tobacco-specific nitrosamines and microbial populations during flue-curing of tobacco under direct and indirect heating; Beitr. Tabakforsch. Int. 21 (2004) 40-46.

8. Burton, H.R., L.P. Bush, and M.J. Djordjevic: Influence of temperature and humidity on the accumulation of tobacco-specific nitrosamines in stored burley tobacco; J. Agric. Food Chem. 37 (1989) 1372-1377.

9. Duncan, G.A., M. Montross, J. Calvert, D. Smith, and D. Mereand: Ongoing studies of barn, field and chamber curing environments on TSNA formation in burley tobacco; Presented at the 2002 CORESTA Congress, New Orleans, USA, September 22-27, 2002.

10. de Roton, C., L.H. San, and B. Vidal: Influence of curing procedures and nornicotine potential on TSNA formation in three varieties of dark tobacco; Joint Meeting of the CORESTA Agronomy and Phytopathology Study Groups, Suzhou, China, October 10-14, 1999.

11. de Roton, C., I. Wahlberg, and A. Wiernik: Burley variety, curing environment, nornicotine conversion and TSNA accumulation; Joint Meeting of the CORESTA Agronomy and Phytopathology Study Groups; Bucharest, Romania, October 12-17, 2003.

12. Rundlöf, T., E. Olsson, A. Wiernik, S. Back, M. Aune, L. Johansson, and I. Wahlberg: Potential nitrite scavengers as inhibitors of the formation of $\mathrm{N}$ nitrosamines in solution and tobacco matrix systems; J. Agric. Food Chem. 48 (2000) 4381-4388.

13. Shapton, D.A and N.F. Shapton: Principles and practices for the safe processing of foods; ButterworthHeinemann Ltd., 1991, pp. 224-225.

14. Coussirat, J.C. and P. Schiltz: Mise en évidence du phénomène de conversion chez les Nicotianées et identification de l'hérédité [Rapid method of showing conversion on nicotine to nornicotine in Nicotianae and identification of heredity]; Ann. du Tabac, Section 2 , 10 (1973) 85-93. 
15. Fayeulle, J.P., L. de Salles de Hys, B. Duméry, J.C. Coussirat, and R. Delon: La nornicotine chez les variétés industrielles de tabac. I. Etat des connaissances, suivi du caractère et efforts visant à son élimination par sélection [Nornicotine in industrial varieties of tobacco. I. State of knowledge, follow-up of character and efforts to eliminate nornicotine in selection]; Ann. du Tabac, Section 2, 24 (1992) 13-26.
Corresponding author:

Christian de Roton

Institut du Tabac de Bergerac

Domaine de la Tour,

24100 Bergerac,

France 